\title{
THE ISLAMIC LAW PERSPECTIVE OF PRECAUTIONARY PRINCIPLE ON TRANSBOUNDARY MOVEMENT OF LIVING MODIFIED ORGANISMS (LMOS)
}

\author{
Sri Wartini \\ * Pengajar Fakultas Hukum Universitas Islam Indonesia, Yogyakarta \\ Korespondensi:sri.wartini@uii.ac.id \\ Naskah dikirim: 27 Juni 2016 \\ Naskah diterima untuk diterbitkan: 10 September 2016
}

\begin{abstract}
The aim of the research is to examine the Islamic law perspective of precautionary principle on transboundary movement of living modified organisms (hereinafter LMOs) based on maslahah mursalah (public interest) and sadd al-dhara'i (blocking the means). The international trade of LMOs may affect the human health and environment in the importing states. Most of the importing states are Muslim states. Thus, it is important to examine the transboundary movement of LMOs from the Islamic law perspective. In order to elaborate on the issue, the reseach addresses the following questions: First, how is the relationship between man and nature (khalifahand nature)? Second, what are the basic Islamic principles relevant to transboundary movement of LMOs based on justice and equality. Finally, it examines comprehensively what are the justification of implementing Precautionary Principle based on maslahah mursalah and sadd al-dhara' $i$ on transboundary movement of LMOs. The research finds that the precautionary principle is justiviable based on based on maslahah mursalah and sadd al-dhara' $i$ on transboundary movement of LMOs.
\end{abstract}

Keywords: precautionary principle, LMOs, GMOs, LMOs trade, maslah mursalah, sadd al dharai

\begin{abstract}
Abstrak
Tujuan dari penulisan ini adalah untuk menganalisa perspektif hukum Islam tentang prinsip kehati-hatian (precautionary principle) dalam perdagangan organisme yang dimodifikasi (LMOs) berdasarkan maslahah mursalah (kepentingan umum) dan sadd al-dhara' $i$ (blocking the mind). Perdagangan LMOs dimungkinkan mempengaruhi kesehatan manusia dan lingkungan. Sementara newgara yang mengimpor LMOs kebanyakan adalah negara yang mayoritas pebduduknya beragana Islam (Muslim State). Oleh karema itu, penting untuk perdagangan LMOs dalam perspektif hukum Islam. Untuk lebih mengelanorasi masalah tersebut, penelitian ini akan menjawab pertanyaan/permasalahan sebagai berikut: Pertama, bagaimana hubungan antara manusia sebagai khalifah dengan alam ? Kedua, apakah prinsip dasar hukum Islam yang relevan digunakan untuk melakukan perdagangan internasional LMOs? Selanjutnya, tulisan ini menganalisa secara komprehensif justifikasi penerapan prinsip kehati-hatian berdsarkan maslahah mursalah dan sadd al dhara'i dalam perdagangan LMOs. Adapun hasil dari penelian ini bahwa prinsip kehati-hatian dapat dibenarkan berdasarkan maslahah mursalah and sadd al-dhara'i dalam perdagangan LMOs
\end{abstract}

Kata Kunci: prinsip kehati-hatian, LMOs, GMOs, perdagangan LMOs, maslah mursalah, sadd al dharai. 


\section{Introduction}

According to Article 2(k) of the Cartagena Protocol, "transboundary movement" means the movement of LMOs ${ }^{1}$ from one Party to another Party, save that for the purpose of Articles 17 and 24 transboundary movement extends to movement between Parties and non-Parties. Recognising that LMOs has adverse latent impacts on human health and the environment, the Cartagena Protocol designed an international framework to assist countries to deal with LMOs.It compels Parties to guarantee that the development, handling, transport, use, transfer and release of any LMOs is done in such a way that it precludes or abates the risks to biological diversity. ${ }^{2}$

In case of an adverse impact of LMOs, it is necessary to implement precautionary principle (hereinafter PP) in international trade agreements. PP is a concept in the field of environmental law in order to mitigate risk to human health and the environment caused by the lack of scientific certainty, and to justify regulatory action in situation where in action can lead to possibly irreversible damage. ${ }^{3}$ According to Rio Declaration on Environment and Development Article 15 defines PP as followed :

\section{In order to protect the environment, the precautionary approach shall be widely applied by states according to their capabilities. Where there are threats of serious or irreversible damage, lack of full scientific certainty shall not be used as a reason for postponing cost-effective measures to prevent environmental degradation. ${ }^{4}$}

This attempts to persuade states to take precautionary measures, even though the potential harm has not yet been proven, with the scientific certainty. In the absence of scientific certainty, it does not imply that measures need not be

\footnotetext{
${ }^{1}$ Article $3(\mathrm{~g})$ of the Cartagena Protocol states : "Living modified organism" means any living organism that possesses a novel combination of genetic material obtained through the use of modern biotechnology; While Article (h) states : "Living organism" means any biological entity capable of transferring or replicating genetic material, including sterile organisms, viruses and viroids". Furthermore in Article 3(I) states " Modern biotechnology means the application of : (1) In vitro nucleic acid techniques, including recombinant deoxyribonucleic acid (DNA) and direct injection of nucleic acid into cells or organelles, or (2) Fusion of cells beyond the taxonomic family, that overcome natural physiological reproductive or recombination barriers and that are not techniques used in traditional breeding and selection.The Cartagena Protocol uses the term "LMOs" for what is actually as Genetically modified organisms (GMOs). Third World Network Biosafety Information Service, Biosafety Protocol Steps Forward, 〈http://www.biosafety.info.net/file dir/516179244cbe5ce34ca39.pdf>, accessed on 28 February 2010.

2 Thomas P. Redick, The Cartagena Protocol On Biosafety: Precautionary Priority In Biotech Crop Approvals and Containment of Commodities Shipments, "Colorado Journal of International Environmental Law \& Policy”, Vol. 18, No. 2, 2007, pp. 54-55.

3 John O’Brien, International Law, (United Kingdom: Cavendish Publishing Limited, 2002), p. 566.

${ }^{4}$ Article 15 of the Rio Declaration on the Environment and Development
} 
taken. ${ }^{5}$ It sets forth no positive obligation. It simply reminds the legislators that they cannot wait for proof of a cause-effect linkage between a given substance, process or activity and environmental harm before acting to reduce or eliminate the risk of this harm. In fact, the second sentence of Principle 15 of the Rio Declaration which might be considered as the essence of a PP.

While in this era of free global trade, trade law has directly opposed the foundation upon which PPis based. Trade restrictions intended to protect a country's domestic industry have been found to be direct violation of free trade laws. ${ }^{6}$ Critics of the PP claim that it will, in effect, contravene the principles of free trade and give other nations an indiscriminate right to reject certain kind of goods in future. The most sensitive issue is, under what conditions that states can take a unilateral measure? Even where there is sufficient scientific evidence to satisfy international standards, a country can still conceivably impose precautionary measures simply because it does not believe in scientific tests $^{7}$

Therefore, the Cartagena Protocol attempts to protect biodiversity and human health against adverse effects resulting from handling and transboundary movement of LMOs. ${ }^{8}$ However, continuous increasing trade in LMOs particularly in agriculture, has triggered much debate concerning the scientific disadvantages and potential dangers of LMOs to humans and the environment. ${ }^{9}$ LMO producers highlight the benefits of LMOs, including insect resistance, increased production, resistance to adverse weather, and reduced need for pesticide.

Indeed, the commodities that enter into global trade are numerous. One of the new commodities, which is available on the global trade, is living modified organisms (hereinafter LMOs), such as herbicide resistant tolerant soybean, bacillus thuringiensis maize (hereinafter $\mathrm{Bt}$ maize)Maize, ${ }^{10} \mathrm{Bt}$ cotton,

${ }^{5}$ Abdul Haseeb Ansari, Parven Jamal \& Maizatun Mustafa, "Meaning, Scope and Implementation of the Precautionary Principle: A Critical Appraisal," in Land Use Planning and Environmental Sustainability in Malaysia, ed. Hunud Abia Kadouf and Sharifa Zubaidah Al Junid (Kuala Lumpur: IIUM, 2006), p. 120.

6 Robert V. Percival, Who is Afraid of the Precatuionary Principle?, "Pace Environmental Law Review”, Vol. 23 (2005-2006), p. 27.

7 Marc Victor, Precatuionary or Protectionism? The Preautionary Principle, Genetically Modified Organisms, and Allowing Unfounded Fear to Undermine Free Trade, “The Transnational Lawyer”, Vol. 14 (2001), p. 319.

${ }^{8}$ Article $3(\mathrm{k})$, the Cartagena Protocol states: "Transboundary movement" means the movement of LMOs from one Party to another Party, save that for the purpose of Articles 17 and 24 transboundary movement extends to movement between Parties and non-Parties.

${ }^{9}$ Secretariat of The Convention on Biological Diversity Biosafety, Handbook of The Convention On Biological Diversity, (London: Earthscan Publication Ltd, 2001), p. 29.

${ }^{10}$ Lakshman D. Guruswamy, Sustainable Agriculture: Do GMOs Imperil Biosafety?, "Indian Journal of Global Legal Studies", Vol. 9 (2002), p. 466. He states that B.t. is a soil bacterium that is fermented to create a commercial insecticide (B.t.spray) that is biodegradable and safe for humans and non-target organisms. Genes expressing B.t. toxins have been engineered into a number of plants including tobacco, potatoes, maize, and cotton. Another approach inserts genes into organisms that are naturally insecticidal to make them efficient as insect pathogens. 
Bt Potato, ${ }^{11}$ and Bt Brinjal. ${ }^{12}$ These agricultural products can be classified as genetically modified (hereinafter GM) which may have potential adverse impacts on humans, animal or plant life or health and environment. Unfortunately, they have been supplied to international as food stuff especially to many developing countries and least developed countries. Most of them are Muslim states. ${ }^{13}$ According to Fazlun M. Khalid, "a Muslim State is a state in which the majority of people are Muslims". Indeed, there are about 60 such states in the world, including Indonesia.

Thus, it is important to examine the transboundary movement of LMOs from the Islamic Law perspective. In order to elaborate on the issue, this chapter critically scrutinises the requirements that LMOs to be manufactured, exported and imported have to be lawful (halal) and good (tayyib). Therefore, this research highlights the applicability of maslahah mursalah and sadd al dhara' $i$ on transboundary movement of LMOs. Furthermore, the research also discusses the relationship between man and nature (khalifah and nature). This is followed by the examination of basic Islamic principles relevant to transboundary movement of LMOs based on justice and equality according to Islamic perspective. Third, the Islamic law perspective of PP and the permissibility of PP based on maslahah mursalah and sadd al-dhara' $i$ on transboundary movement of LMOs are intensely analysed. Finally, it will followed by conclusion.

\section{Statement of Problems}

Based on the background which is mentioned previously, the questiones of the research are:

1. How is the relationship between man and nature (khalifah andnature) based on Islamic Law perspective?

2. What are the basic Islamic law principles relevant to transboundary movement of LMOs according to Islamic Law perspective?

3. How is the Islamic law perspective of PP and the permissibility of PP based on maslahah mursalah and sadd al-dhara'i on transboundary movement of LMOs ?

\section{Objective of the Research}

The objective of the research is to analyze to what the extent the relationship between man and nature (khalifahand nature), secondly, It

11 Josept M. Gopo, Biosafety and Trade: Issues for Developing Countries, Bellevau, Switzerland 18-10 July 2001, www.ictsd.org, accessed on 24 July 2008.

12 G. Shanmugan, The BtBrinjal Debate, <http://www.las.ac.in/currsei/25 jan 2011/147.pdf>, accessed on 22 February, 2011. It has not yet been allowed by the Indian Government to be marketed. It is subject to further lab and field testing.

13 Fazlun M. Khalid, "Islam and Environment," in Encyclopedia of Global Environmental Change, ed. Peter Timmerman (Chichester John Wiley \& Sons, Ltd., 2002), p. 3. 
examines the basic Islamic principles relevant to transboundary movement of LMOs according to Islamic Law perspective and, finally, it analyses compehensively the Islamic law perspective of PP and the permissibility of PP based on maslahah mursalah and sadd al-dhara' $i$ on transboundary movement of LMOs.

\section{Research Method}

This research is a normativve research. The methodology employed in this research is library-based research. While the approaches employed in the paper is a conceptual approach. The main research materials used in the research are primary and secondary sources. The primary materials are AlQur'an, Hadith, Cartagena Protocol, General Agreement on Tariffs and Trade, Rio Declaration, and Stockholm Declaration. The secondary sources consist of books, journal, report and internet sources which are relevant to the subject matter.

\section{Research Findings/Results}

\section{The Relationship Between Man And Nature: Vicegerency and Trusteeship (Khalifah and Amanah)}

Muslims believe that in order to understand the relationship between man and nature, man has to refer to the Qur'an ${ }^{14}$ and Hadith as the primary sources of Islamic Law. ${ }^{15}$ In Islam, every right comes with a corresponding responsibility. Human beings do not own the Earth. ${ }^{16}$ Therefore, $\operatorname{man}^{17}$ isresponsible for taking care of the earth and whatever resources it contains in a responsible manner. With increasingly frequent and extreme abnormal natural phenomena, the world's attention has shifted towards climate change and humans' role in the rapid destruction of our environment. ${ }^{18}$ Man has been charged by Allah as a leader of humankind. Therefore, man has a religious and

14 The translations all the verses of the Qur'an which are used in research refers to "Qur'an Viewer 2.8" the English Transliteration by Abdullah Yusuf Ali, Commentary Chapter Introductions by Scholar, Shed Abu Al Maududi, Transliteration Text by Muslim Net, adapted by Jamal Al-Nasir with modification.

15 Mohammad Hashim Kamali, Principles of Muslim Jurisprudence (United Kingdom: Cambride, The Muslim Text Society, 2006), p. 1. See, Muhammad Hamidullah, The Muslim Conduct of State, (Hyderabad-Deccan, 1977), p. 18. See also, Abdullahi Ahmad An-Na'im, Toward an Muslim Reformation, Civil, Liberties, Human Rights, and International Law (New York: Syracuse University Press, 1990), p. 11.

16 Saiyed F. Al-Khouli, On Islam Attitude Towards Sustainable Development, <http://www.isesco.org.ma/english/publications/Sust_Der/P6.php>, accessed on 20 January, 2010.

${ }^{17}$ Man includes woman and vice versa, unless otherwise stated.

18 Muzammal Hussain, Islam and Climate Change: Perspectives and Engagement, 〈http://www.lineonweb.org.uk/Resources/reading.htm>, accessed on 20 December, 2009. See also, Faroog Hassan, Islam: Environmental Protection, <http://www.greaterdemocracy.org/archieves/000507.html>, accessed on 10 January, 2009. 
moral duty to be at the forefront of promoting environmentally sustainable practices.

Humans are equal partners in everything that is of common interest in the natural world ${ }^{19}$ however, they have responsibilities to conserve the natural world so that the benefit continues. Humans are definitely not its lords and masters but its guardians. However, when man manufactures LMOs to create certain kinds of genetically modified crops (hereinafter GM crops) ${ }^{20}$ by using biotechnology, they must not disturb or damage the balance of the ecosystem. ${ }^{21}$ The manufacturing, exporting and importing of GM crops and GM food derived from GM crops may affect the human health and the environment. ${ }^{22}$

It is not permissible to abuse one's rights as a vicegerent (khalifah), because the notion of acting in "good faith" underpins Islamic law. ${ }^{23}$ The planet is inherited by all humankind and "all its posterity from generation to generation.... Each generation is only the trustee". ${ }^{24}$ No one generation has the right to pollute the planet or consume its natural resources in a manner that leaves for posterity only a polluted planet ${ }^{25}$

19 Ben Adam, The Creation of Environmental Conscience (part 2 of 4): Man-God's Steward on the Earth, <http://www.islamreligion.com/articles/334.html $>$, accessed on 25 January, 2010.

${ }^{20}$ GMOs are produced by inserting foreign genes into the recipient organism's cells. There are three major techniques commonly used to insert foreign DNA into a plant genome, all of which rely on recombinant vectors to carry the foreign DNA. The most common technique uses bacteria to transfer a piece of the bacteria's own DNA into the host plant cells. The second technique involves the use of microinjection, electroporation, or chemical treatment whereby the DNA is inserted into the plant protoplast (a plant cell without a cell wall). The third technique is mechanical, relying on high velocity ballistic delivery or microprojectile bombardment to convey the DNA into the plant cells. See, Antonia Aliason, "ScienceVersus Law in WTO Jurisprudence: The (Mis)interpretation of the Scientific Process and the (In)sufficiency of Scientific Evidence in EC-Biotech,"New York University Journal of International Law \& Policy 41(Winter, 2009), pp. 49-350.

${ }^{21}$ The Qur'an, 15:19.

And the earth We have spread out (like a carpet); set thereon mountains firm and immovable; and produced therein all kinds of things in due balance.

See Abdul Haseeb Ansari and Parveen Jamal, "Towards an Muslim Jurisprudence of Environment: An Expository Study", in Religion and Law Review, ed. S. Chalid Rashid (New Delhi: Institute of Objective Studies), vol. X-XI, at 86-87. See also, Rached Al-Jayyousi, Grey Water: Muslim Perspective, <http://www.idrc.ca/cp/ev-152692-20/-I-Do_ToP/c.html>, accessed on 24 February, 2010.

${ }^{22}$ Cynthia Dresden, Biotechnology in the Balance of International Trade: Scientific Uncertainty and Legal Response, "International Trade Law Journal", Vol. 12, (2003), p. 45.

${ }^{23}$ Hussein A. Amery, Islam in the Environment, <http://www.idre.ca/en/eu.9350-201-IDo-Topic.html>, accessed on 23 February, 2009. See also, Lucita Ball, Green Deen vs Gloom and Doom, <http://www.shapworkingparty.org.uk/journals/articles_08109/ball_long.pdf >, accessed on 10 January, 2010.

24 M. Aurangzeb Ahmad, Is A Greener Islam Possible?, 〈http://www.altmuslim.com/a/a/a/is_a_greener_islam_possible?Aurangzeb〉, accessed on 24 May, 2010. See also, Ansari and Jamal, op. cit., p. 86.

${ }^{25}$ Hafiz Nazeem Goolam, Preserving Paradise Through Religious Values of Nature: Muslim Approach, <http://www.fs.fed.us/rm/pubs/rmrs_p027/rmrs_p027_105_166.pdf>, accessed on 24 January, 2009. 
or one seriously denuded of its resources. In other contexts, the concept of vicegerency (khalifah) refers to the fact that waves of humanity will continuously succeed each other and inherit planet earth.

Islam urges moderation in consumption, encourages man to avoid wasteful use of natural resources, ${ }^{26}$ and enjoins mankind to maintain the natural balance. As a result, when man manufactures the GM crops, such gesture must not disturb the normal balance of the natural resources. ${ }^{27}$ Indeed, the Qur'an states that Allah created all things in measure and proportion. ${ }^{28}$ Thus, as a vicegerent man has to maintain the balance of the ecosystem for sustenance of the human beings and other creatures. ${ }^{29}$

Islamic teachings as contained in the Qur'an and Sunnah enjoin Muslims to avoid and prevent mischief $($ fasad $),{ }^{30}$ which encompasses undueexploitationor degradation of environmental resources, including biodiversity. This perspective is especially revealing in the light of the Islamic belief that the natural world is obedient to the human world. ${ }^{31}$ Therefore, humans are permitted to use and transform the natural environment, with which they are entrusted, to serve their survival needs. For example, Allah states that humans may use His resources

26 F. Kamal, Islam and the Environment, <http://www.easily-understandislam.com/articles/Islam-environme.html >, accessed on 15 January, 2010.

${ }^{27}$ See, the Qur'an, 6:142.

See also, Fazlun M. Khalid, "Islam and Environment," in Encyclopedia of Global Environmental Change, ed. Peter Timmerman (Chichester John Wiley \& Sons, Ltd, 2002), p. 3.

28 See, the Qur'an, 54:49.

Verily all things have We created in proportion and measure.

See also, the Qur'an, 25:2 in part:

... It is He who created the heavens and the earth in due proportions.

${ }^{29}$ Islam Set, Science Environment and Technology, General Introduction to Islam's Attitude toward the Universe, Natural Resources and the Relation between Man and Nature, <http://www.islamset.com/env/index.html $>$, accessed on 20 January, 2010. See also, Islam from Inside, Man and Ecology: An Muslim Perspective, <http://www.islaminside.com/Pages/Articles/Ecology\%20Environment\%20and\%20Islam.html $>$, accessed on 16 February, 2010.

${ }^{30}$ See, the Qur'an, 55:8.

In order that you may not transgress the balance.

See, the Qur'an, 7:85 in part:

... Give just measure and weight, nor withhold from the people the things that are their due; and do no mischief on the earth after it has been set in order: that will be best for you, if you have faith.

Rahma Hersi, "A Value Oriented Legal Theory for Muslim Countries in the $21^{\text {st }}$ Century: A Comparative Study of Both Muslim Law and Common Law Systems", LL.M. Thesis Indiana University School of Law 2009.

31 Ali Ahmad, Cosmopolitan Orientation of the Process of International Environmental Law Making, (Boston, University Press of America, Inc., 2001), p. 61. See. Mohammed I. Ansari, Muslim Perspective on Sustainable Development, <http://iepistimology.net/attacthments/406_V1IN3\%6Fall\%2094\%20Ansari\%20$\%$ 20Muslim\%Perspectives \%20on\%20Sustainable\%20Development.pdf $>$, accessed on 12 January, 2010 . 
(good) for their sustenance on the condition that they commit no excesses. $^{32}$

The trusteeship (amanah) concept emphasises that the beneficiary of natural resources is not only the present generations but also the future generations. Indeed, everything created by Allah between the sky and the earth are for the benefit of man, he has been commanded as vicegerent of Allah to take the advantage of such benefit and maintain the divine orderliness. ${ }^{33}$ This is because the benefit in such resources can be better explored if ecological balance is maintained as its components are inter-related and interdependent. ${ }^{34}$

However, man as a trustee should not alter or disturb the ecological balance $^{35}$ when he manufactures LMOs by using biotechnology. The use of natural resources should be in accordance to the sustainability of such resources. Human beings ought to utilise the resources to sustain their biological needs. Current users of LMOs in the form of GM crops to accomplish the need of the people in most developing countries should avoid irreversible damage so thatthe resources can serve humanity's current and future needs. Thus, the concept oftrusteeshipis in line with the PP, because based on trusteeship man has a duty to take precautionary measures to prevent adverse impact when there is scientific uncertainty.

The right to utilise and exploit natural resources, which Allah has granted to man, necessarily involves an obligation on man's part to conserve them both quantitatively and qualitatively. ${ }^{36}$ Allah has created all the sources of life for man and all resources of nature that he requires, so that he may realise objectives such as contemplation and worship. However, man has a duty to maintain inhabitation and construction, sustainable utilisation, and enjoyment and appreciation of beauty. ${ }^{37}$ It therefore follows that man has no right to cause the

${ }^{32}$ See, the Qur'an,20:81.

Eat of the good thing We have provided for your sustenance, but commit no excess there in lest My Wrath should justly descent on you: and those on whom descends My Wrath do perish indeed!.

${ }^{33}$ See, the Qur'an, 30:30.

So set thou thy face steadily and truly to the Faith: (establish) Allah's handwork according to the pattern on which He has made (wrought) by Allah: that is the standard Religion: but most among mankind understand not.

${ }^{34}$ See, the Qur'an, 21:16; 55:5-8.

See also, Ansari and Jamal, op. cit., p. 86.

${ }^{35}$ Islam Set, Science Environment and Technology, Legislative Principles, Policies and Institutions of Muslim Law which Govern the Procedure and Measures for the Protection and Conservation of the Environment, <http://www.islamset.com/env/index/html >, accessed on 20 January, 2010.

${ }^{36}$ Islam Green Team, Islam and the Environment, <http://muslimgreenteam.org/Islamand-the-environment>, accessed on 12 January, 2010.

${ }^{37}$ See, the Qur'an, 28:77 in part:

Allah has said "And do good as Allah has been good to you. And do not seek to cause mischief in the earth; for Allah love not to those who do mischief". 
degradation of environment and distort its intrinsic suitability for human life and settlement. Nor has man the right to exploit or use natural resources unwisely in such a way as to spoil the food bases and other sources of subsistence for living beings, or expose them to destruction and defilement. ${ }^{38}$

The perception of Islam to the environment, as the sources of life, and the resources of nature is based on prohibition of abuse and promotion of sustainable development (hereinafter SD). In fact, the embryo of $\mathrm{SD}^{39}$ which was proposed in the Stockholm Conference in 1972 is not a new concept in Islam. As the Islamic teaching of environment elucidates human-environment interactions are guided by the notion of the person as a vicegerent, meaning a custodian of the earth. ${ }^{40}$ Thus, man has an obligation to preserve the environment. The Islamic teaching ofenvironment reflects and embodies the Sustainable development principle. It is submitted that the concept of SDhasexisted in Islamic teachings of environment since the advent of Islam as clearly provided in the Qur' an and numerous traditions of the Prophet. ${ }^{41}$

The concept of $\mathrm{SD}^{42}$ in Islam can be defined as " $[\mathrm{t}]$ he balanced and simultaneous realisation of consumer welfare,economic efficiency, attainment of social justice, and ecological balance ${ }^{43}$ in the framework

See also, Mehmet Usutay, A Political Economic Approach to Muslim Economics: Systemic Understanding for an Alternative Economic System, "Kyoto Bulletin of Muslim Area Studies", (2007), p. 9.

38 See, the Qur'an, 7:56.

Do no mischief on the earth, after it has been set in order, but call on Him with fear and longing (in your hearts): for the mercy of Allah as (always) near to those who do good.

See also, the Qur'an, 5:64.

39 In 1987, the World Commission on Environment and Development defined sustainable development as "development that meets the needs to the present generation without compromising future generation to meet their own needs". See, Alhaji B. M. Marong, From Rio to Johannesburg : Reflections on the Role of International Legal Norms in Sustainable Development, "Georgia International Environmental Law Review”, Vol. 16, (Fall, 2003), p. 24.

40 O. Liewellyn, "The Basis for a Discipline of Muslim Environmental Law," in Islam and Ecology: A Bestow Trust, eds. R. Foltz, F. Denny and A. Baharuddin (Massachusetts: Cambridge: Harvard University Press, 2003), p. 190. See also, Asma Hassan and Zainal Abedien Cajee, Muslims and Sustainable Development: the Message from Johannesburg, <http: //www.imase.org/content/view/27/34/>, accessed on 31 December, 2009.

${ }^{41}$ MohammadHashimKamali, "Environmental in Islam: A Qur'anic Perspective," The Royal Aal al-Bayt Institute for Muslim Thought, the $15^{\text {th }}$ General Conference, 27-29 September, 2010,http://www.aablbyt.org/Env Conference/002.pdf, accessed on 23 December, 2010.

42 Taibu Makwemba, "An Muslim Perspective on Sustainable Development in the Context of Globalisation," Thesis University of Kwazulu-Natal (Westville Campus), South Africa, December, 2004, http://researchspace.ukzn.ac.za/xmlui/bitstream/handle/10413/1526/makwemba_Taibu_2004.p df? sequence $=2$, accessed on 21 June, 2010.

${ }^{43}$ Based on the definition, there are three points that to be sustained: (i) Maintaining the sustainability of economic growth; (ii) Achieving inter-generational equity in the use of the natural resources; (iii) Restricting as far as possible the increase in pollution for maintaining 
of an evolutionaryknowledge-based, socially interactive model defining the Shuraticprocess". 44 Thus, the concept of SD in Islam is in accordance with the three pillars of SD. ${ }^{45}$

A huge number of verses in the Qur'an and several sayings of Prophet Muhammad ${ }^{46}$ indicate the great importance that has been given to environmental concerns and the responsibility of manto the environment. All members of society possess the common right to take benefit from the essential environmental elements and resources such as water, minerals, land, forests, fish and wildlife, arable soil, air andsunlight. Each individual is entitled to benefit from a common resource subject to establishing the degree of need, ${ }^{47}$ and the impact on the environment. Hence, the manufacturing, exporting and importing of LMOs should be for the benefit of all people.

\section{The Fundamental Islamic Principles Relevant to Transboundary Movement of LMOs}

Transboundary movement of LMOs in the forms of export and import can be viewed in positive terms as the key force in promoting worldwide economic development. On the other hand, the exporting and importing of LMOs may have adverse impact to human health ${ }^{48}$ and the environment ${ }^{49}$ However, in order to protect the public health and environment, states should apply the principles of justice in the

the present quality of environment. See, Zubair Hasan, Sustainable Development from Muslim Perspective: Meaning Implications, and Policy Concern, < $\underline{\text { http://ideas.refec.org/pa/mpra }}$ pa/2784.html, accessed on 24 February, 2010.

${ }^{44}$ Karim Hamdy, Muslim Perspectives on Natural Resources Management and Sustainability, <http://oregostate.edu/dept/iifet/2000/papers/hamdy.pdf>, accessed on 23 February, 2010. The "Shuratic process" mentioned here refers to the concept of mutual consultation in decision-making.

45 Three Pillars of Sustainable development are : (i) economic development, (ii) environmental protection, and (iii) social development.

${ }^{46}$ For instance the Prophet, declared, "If any Muslim plants a tree or sows a field, and a human, bird or animal eats from it, it shall be reckoned as charity from him". Hadith Sahih, Buchari book 39, No. 513, Islamsoft-Solution, the Future Toward Universe of Revolutionised Software, <http://www.islamsoft.co.uk>, accessed on 12 February, 2010.

${ }^{47}$ Abul Hassan, On Islam's Attitude towards Sustainable Development,

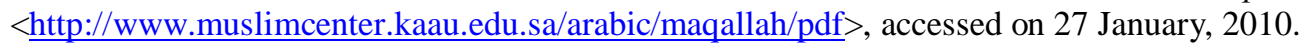

48 The adverse impacts of LMOs to the human health, namely are allergen, antibiotic resistance and toxins. See, Stan Benda, It is all about Elmer Gantry ... There is no Frankenstein! - Part II, "Intellectual Property Journal” Vol. 16, (June, 2003), p. 400. See also, Cora V. Coburn, Out of the Petri Dish and Back to the People: A Cultural Approach to GMO Policy, “Winsconsin International Law Journal”, Vol. 23, (2005), pp. 287-288.

49 The adverse impacts of LMOs to the environment namely, are superweeds, harm to non-target organism, and harm to the biodiversity. Heather D Heavin, The Biosafety Practice and the SPS Agreement: Conflict and Dispute Resolution, "Journal of Environmental Law \& Practice” Vol. 12, (November, 2003), p. 374. See Holly Saigo, Agricultural Biotechnology and the Negotiator of the Biosafety Protocol, "Georgia International Environmental Law Review", Vol. 12 (Spring, 2000), p. 789 
export and import of LMOs. Justice in Islamic perspective is revealed in the Qur'an thus:

...O you who believe! Be upright, for the sake of Allah in testifying for fairness; and do not let the hatred of a people urge you to be unjust, be just, that is closest to Godliness. Fear (from displeasing) Allah verily is aware of what you do. ${ }^{50}$

This verse demonstrates that Allah orders Muslim to be fair and apply justice to other people. The verse is aimed at individual human beings. Nonetheless, it can also be applied in the state relationship which includes the Muslim States as the Members of the WTO, because the exporting and importing of LMOs fall under the authority of the states.

Besides that, according to the verse, it can be inferred that the nondiscrimination principle stipulated in the WTO, such as national treatment and most favoured nation ${ }^{51}$ are in line with the concept of justice in Islam, ${ }^{52}$ because the principles treat all the WTO Members equally based on the rights and obligations which are stipulated in theWTO. For instance, if LMOs (in the form of GMO crops) from United States can enter the Indonesian market,then GMO crops from other countries should be able to enter the Indonesian market. Thus, there is no different treatment among the states. Thus, the Muslim states as the Members of the $\mathrm{WTO}^{53}$ have to comply with all the obligations stipulated in the WTO Agreements.

According to Kamali, literally justice (' $a d l$ ) means placing something in its rightful place where it belongs. ${ }^{54}$ It also means according equal treatment to others or reaching a state of equilibrium in transactions with them.Justice is closely related to equality in that it aims at a state of equilibrium in the distribution of rights and duties, advantages and burdens of the society. ${ }^{55}$ Therefore, it is essential to

${ }^{50}$ See, the Qur'an, 5:8.

51 Basic rights and obligations in international trade, namely are : (i) not making a distinction between goods from different countries, unless this is provided for in the agreement; (ii) not discriminating against imported goods, in favour of locally-produced goods; Andrew Thomison, A New and Controversial Mandate for the SPS Agreement: The WTO Panel's Interim Report in the EC-Biotech Dispute, "Columbia Journal of Environmental Law Journal”, Vol. 32, (2007), p. 289.

52 Khaled Abou El Fadl, Islam and the Challenge of Democracy, <http://www.princeton.edu/iisd/project/PORDIR/research/khalid\%20Abau\%20E520Fadl.pdf $>$, accessed on 20 December, 2010.

${ }^{53}$ Haniff Ahamat, The Position of Siyar on Free Trade A Historico - Legal Analysis, “Journal of the History of International Law”, Vol. 12, (2010), pp. 320-321.

${ }_{54}$ Mohammad Hashim Kamali, Freedom, Equality and Justice in Islam, (Malaysia, Ilmiah Publishers and The Muslim Foundation, 1999), p. 140.

55 Masudal Alam Choudhury, The Humanomic Structure of Muslim Economic Theory: A Critical Review of Literature in Normative and Positive Economics, <http://www.kantaleji.com/figh/Files/Economics/10058.pdf>, accessed on 14 February, 2010. 
apply justice and equality concepts in export and import of LMOs. ${ }^{56}$ If the importing and exporting of LMOs ignore these concepts, the sustainability of international trade of LMOs and protection of human health and the environment may be affected, because the importing and exporting states may abuse their rights and obligations. By applying principles of justice and equality, there will be a guarantee that the importing and exporting state exercise their rights and obligation properly and cautiously. Therefore, states should not undertake an action or instigate a business transaction that will cause greater harm than benefit to the community or environment of other states. ${ }^{57}$

Nevertheless, when Muslim states get involved in export and import of LMOs, they also have to apply justice in the transaction (export and import) by exercising the rights and obligation as exporting states or importing states. There should be a transparency of information in accordance with the Sanitary and Phytosanitary Agreement and the Cartagena Protocol, because as the Contracting Parties of both Agreements, a Muslim state has to comply with the obligations andmechanism of the two agreements. Additionally, in theIslamic Law of Obligations, Muslims are bound by their agreements, especially when such involve things that affect the lives of the people. ${ }^{58}$

The concept of justice in Islam can be found in the Qur'an and Sunnah. ${ }^{59}$ The centrality of justice to the value structure of Islam is vividly portrayed in the following Qur'anic verse: "We sent Our Messengers with clear signs and sent down with them the Book and the measure in order to establish justice among the people." 60 Thus, justice is a central value in Islamic teaching and is considered to be the

See also, Securities Commission Malaysia, Muslim Commercial Law (Fiqh al-Muamalat), (Selangor, Malaysia: Lexis Nexis Malaysia Sdn. Bhd., 2009), pp. 36-37. See also, Mohammad Hashim Kamali, Shari 'ah Law an Introduction, (England: Oneworld Publication, 2008), p. 114 .

${ }^{56}$ See, The Qur'an, 4:135 and theQur'an, 16:90.

Rafik I. Beekun and Jamal A. Badawi, Balancing Ethical Responsibility Among Multiple Organisational Stakeholder: The Muslim Perspective, <http: www.business.unr.edu/faalty/beekun/beekun\%20and\%20Badawi\%20JBE\%20pub.pdf>, accessed on 23 November, 2009.

${ }^{57}$ Mohammad Hashim Kamali, Muslim Commercial Law An Analysis of Futures and Options (Selangor Malaysia: Ilmiah Publishers, 2002), p. 70. See also, Discover Islam Web, Economics Principles of Islam, <http://www.witness.pioner.org/vil/Books/Mf_ICIT/Islam_principle.html >, accessed on 8 February, 2010.

${ }^{58}$ Liaquat Ali Khan Niazi, Muslim law of Contract, (Lahore: Research Cell, Dyal Sing Trust Library, 1998), pp. 9-16. See also, Mohd Ma'sum Billah, Applied Muslim Law of Trade and Finance, A Selection of Contemporary Practical Issue, (Selangor, Malaysia: Sweet and Maxwell Asia, 2007), pp. 152-153.

59 Abdullah Ahmad An-Na'im, Toward an Muslim Reformation, Civil Liberties, Human Rights, and International Law, (New York: Syracuse University Press, 1990), p. 11. See, Moral Stories, Which is Superior: Justice or Generosity? Concept of Justice in Islam, <http://www.ezsoftech.com/Stories/justice.in.islam.atp>, accessed on 20April, 2010.

${ }^{60}$ See, the Qur'an, 57:25. 
foundation for all Allah's creation. ${ }^{61}$ According to the teachings of the Qur'an, any actions and deeds of humankind that contravene justice are an act of corruption on earth, and therefore, the Qur' anic teachings focus on promoting and enforcing a code of ethics and morality for human behaviour. ${ }^{62}$ In the Qur'an many verses promote universal values, which should define the relationship that humans have with Allah and all creation, among which are: justice and equality, which are important for human happiness, peace, progress and prosperity. ${ }^{63}$ According to theQur'an, establishing justice has been the goal of all prophets and messengers of Allah's revelations.

While, the concept of justice according to the messenger (Muhammad PBUH as head of state) practically demonstrated the true meaning of equality and justice, and clearly spoke about this in his last sermon:

O people! If I have flogged anyone [wrongly], let him retaliate here and now. If I have insulted anyone, let him reciprocate. If I have taken anyone's property, let him claim it and take it from me. Let no one fear any rancour on my part, for that would not be becoming of me. Be aware that one who takes back his right from me is most dear to me, for I wish to meet my Lord with a clear conscience. ${ }^{64}$

Against the above background, it is important to expound on the case study of this research which is the theft case of the Makhzumiwoman where equality was displayed in the administration of justice. The Prophet went on record to confirm that he would enforce the law on his own family if there were occasion for him to do so. A'ishah narrated that the Quraish tribe were too concerned when a Makhzumi woman committed theft and the Messenger of Allah wanted to apply the corporal punishment in her case by amputating her hand. The Quraishites tribe consulted among themselves after a series of attempted intercession by a number of Companions, "The best person to talk about the Makhzumi woman thief to the Prophet is his most beloved Companion (and the son of his most beloved companion)

61 Securities Commission Malaysia, Muslim Commercial Law (Fiqh al-Muamalat), (Selangor, Malaysia: LexisNexis Malaysia Sdn. Bhd., 2009), pp. 36-37. See also, Islam Religion, Justice in Islam, <http://www.islamreligion.com/articles/376 $>$, accessed on 4 July, 2010. Sustainable Development, $\quad$ http://www.Muslim-

62 Mamoun Abuarqub, Muslim Imperatives to Curb Corruption and Promote relief/com/Indepth/Downloads/Muslim\%20imperatives\%20to\%20curb\%20corruption\%20pro mote\%20sustainable\%20development.pdf>, accessed on 21 June, 2010.

${ }^{63}$ Ibid. See also, M. Umar Chapra, Muslim Civilisation the Causes of Decline and the Need for Reform, (United Kingdom: the Muslim Foundation, 2008), pp. 20-21.

${ }^{64}$ Ibn Ishaq, The Life of Muhammad, A. Guillaume, Trans. (London: Oxford University Press, 1955), pp. 552-553. 
UsamahibnZayd. Thus Usamah approached the Prophet to grant pardon to the woman who had committed theft as she was newly converted to Islam. Upon listening to Usamah, the Prophet said: "O Usamah! Are you coming to intercede concerning a corporal punishment set by Allah?" Allah's Messenger stood up, as soon as he finished his conversation with Usamah and delivered a speech in annoyance:

The people (or nations) before you were destroyed due to the fact that when a noble person among them would steal, they let him go unpunished, but if a poor, weak and gullible person among them steals they will apply the punishment to him. By Allah! If Fatimah, the daughter of Muhammad stole I shall [not hesitate to] cut her hand. ${ }^{65}$

From the speech of the Prophet it is clear that penalties, judgements and legal sentences are applicable to all classes of people without any distinction. There are no particular forms of penalties or sentences for a certain class of people. All people are equal within the jurisdiction of Islamic law. No individual or class of people has immunity over and above the Islamic laws.

The Rightly-Guided Caliphs followed the Prophet's precedents and claimed no privilege vis-à-vis the rule of law and equal treatment before the courts of justice. ${ }^{66}$ This equality in the administration of justice gives no room for executive immunity on the part of the head of state of a privileged caste in the society. As for equality before the courts of justice, no one, including the head of state, enjoys any exceptional privileges, and everyone is to be treated equally before the law. ${ }^{67}$

Therefore, in order to protect the public health and environment the importing states (most of them are Muslim States) have to guarantee that the exporting and importing of LMOs are based on justice and truthfulness in business transaction. ${ }^{68}$ For instance, all states have to obey the mechanism that has been established in the Cartagena Protocol and the Sanitary and Phytosanitary Agreement. Thus, states are prohibited to abuse the mechanism for the sake of protectionism.

The importing and exporting states of LMOs should maintain their obligations to preserve and sustain the natural resources. The exporting of LMOs to the Muslim states should not cause pollution in the biodiversity or create super weeds and should not cause diseases to

65 This Hadith is related in Sahih Al-Bukhari, Book 81, No. 778. The Hadith was narrated by Ó'ishah. Also see Imam Muslim, Mukhtasar Sahih Muslim, vol. 6, Abdul Hamid Siddiqi, trans., (New Delhi: Kitab Bhavan, 2000), p. 2.

${ }^{66}$ Sheikh Mohd Iqbal, Muslim Toleration and Justice Non-Muslims under Muslim Rule, (New Delhi: Adam Publishers and Distributors, 2005), pp. 93-94.

${ }^{67}$ Farooq Hassan, The Concept of State and Law in Islam, (Boston: University Press of America, Inc., 1981), pp. 199-200. See also, Kamali, op. cit., pp. 65-68.

68 Abdullah Alwi Haji Hassan, Sales and Contract in Early Muslim Commercial Law, (New Delhi, India: Kitabbhavan, 2006), p. 16. See also, Billah, op. cit., p. 38. 
human health. Thus, all actions of man are accountable to Allah. As a result, the economic resources available in a country should be properly organised and utilised. ${ }^{69}$ The importance of justice as a human value is emphasised in the following verse: "... give full measure and full weight with equity, and defraud not people of their things and commit not iniquity in the earth, causing disorder". ${ }^{70}$ Therefore, one can conclude that Islam has promoted morality and justice for the betterment of humankind, which in turn promotes environmental balance, social harmony, peace and security. However, the fair trade system should be based on impartial social relationships between producers and workers, as well as between buyers and sellers. Thus, the fair trade system is in accordance to the teaching in Islam which instructs people to defend and to pursue just economic relationship.

On the other hand, the concept of equality is fundamental to the value structure of Islam. ${ }^{71}$ Equality is basically a relative concept which is no absolute equality can be said to exist either in nature or in society. People are naturally different in talents, skills and their usefulness to society. The Qur' anic verse may be cited to confirm this: "He who has made you successors in the land and elevated some of you in rank above others that He may try you by what He has given you". ${ }^{72}$ Despite the fact that this verse refers to differentials in wealth and also in spiritual rank, elsewhere the Qur'an distinguishes men of piety ${ }^{73}$ and knowledge ${ }^{74}$ from those who lack the qualities. The concept of equality in the Qur' an is aimed to human being as an individual equality in the eyes of Allah, however, the concept can be applied also in relation between states, because dualism is not recognised in Islam. ${ }^{75}$

In this respect, fairness in international trade ${ }^{76}$ finds considerable support in Islam, which supports practices and policies that promote Sustainable Development principle. Regarding the exporting and importing of LMOs, the exporting and importing states are on equal

69 Nik Mustapha Nik Hassan, "The Implementation of Justice in Economics and Business," in Islam and Justice, ed. Aidit bin Ghazali (Malaysia: Institute of Muslim Understanding, 1993), p. 55. See also, Zulkifly Hasan, Muslim Perspective on the Competition Law and Policy, <http://www.wbicompro.com/london\%20management/Hasan(402).pdf>, accessed on 26 February, 2010.

70 See the Qur'an. 11:85.

${ }^{71}$ Kamali, op. cit., at 140 .

72 See, the Qur'an, 6:66.

73 See, the Qur'an, 49:13

74 See, the Qur'an, 58:11.

75 Mahdi Zahraa, Characteristic Features of Muslim Law: Perceptions and Misconceptions, “Arab Law Quarterly” Vol. 15, (2000), pp.170-171; C. G. Weeramantry, Muslim Jurisprudence: An International Perspective (Hampshire, London: Macmillan, Houndmills, Basingtoke, 1998), p. 131.

76 See, the Qur'an in part. 4:29 in part: "O You who believe! Do not devour one another's possessions wrongfully - not even by way of trade based on mutual agreement ..." See also, Ibn Taymiya, Public Duties in Islam the Institution of the Hisba, Muhtar Holland, trans. (Leicester: the Muslim Foundation, 1982), p. 142. 
footing, though each state has different economic development and different conditions. Thus, the exporting and importing of LMOs is based on mutual consent and equality. Both the exporters and the importers are equal before the law. Thus, the concept of "fair trade" which aims at promoting Sustainable Development principle is in line with fair trade in Islamic perspective, because this includes the promotion of better environmental practices and the application of responsible methods of production and preserves valuable ecosystems for future generations. ${ }^{77}$

\section{Permissibility of Precautionary Principle on Transboundary Movement of LMOs Based on Maslahah Mursalah}

All natural resources including the biodiversity are considered the right and the joint property of the entire human kind. Since man is the vicegerent of Allah (Khalifah) one arth, he should take every precaution to ensure the interests and rights of others, ${ }^{78}$ and regard his mastery over his allotted piece of land as a joint ownership with the next generations. The rights to benefit from nature are linked to accountability and maintenance or conservation of the resource. Accordingly PP is applied where there are threats of serious or irreversible damage and lack of full scientific certainty. The principle is in accordance to the fundamental legal principle established by the Prophet Muhammad is that the benefit of a thing is in return for the liability attached to it. ${ }^{79}$

For instance, if the utilisation of LMOs for direct introduction to the environment through planting in the importing state, or as direct use of food or feed may cause potential impacts to human health and environment especially biodiversity, the application of PP is justified. Thus, if these conducts cause environmental damage or disease to the human being in the importing states, the exporting states must be liable.

\section{a. The Principle of Maslahah Mursalah}

77 Muslim Relief Worldwide, Environmental Policy, <http://www.muslimrelief.com/Indepth/downloads/Environmental\%20Policy.pdf $>$, accessed on 2 March, 2010. See also, Zaki Jalil, Nature of Progress, <http://www.thereadinggroup.sg/Articles/Nature\%20of\%20Progress.pdf >, accessed on 25 February, 2010.

78 Bawa Muhaiyaddeen, Environmental Protection in Islam (part 1 of 7): General Introduction, http://www.islamset.com/env/index.html, accessed on 20 October, 2009. See also, Saliem Fakir, The Notion of Public goods, Sustainable Development and Islam, $<$ http://www.islam.co.za/awqafsa/public\%20Goods\%20in\%20Islam\%20Fakir.htm>, accessed on 8 February, 2010.

79 Iyat Abumoghli, Sustainable Development in Islam, <http://waterwiki.net/images/8/85/sustainable_development_in_Muslim_law_Iyad_A bumoghli.doc $>$, accessed on 25 January, 2010. 
Manufacturing and transboundary movement of LMOs is new commodity in international trade if it is compared to other commodities such as conventional rice, fruits, and process food. LMOs have not been regulated in the Qur' anand Hadith. Based on the usul al-figh if a certain matter has not mentioned in the primary sources of Shari' 'ah such as the Qur'an, Hadith, consensus (ijma') and analogy (qiyas) the permissibility of the matter can be based on the secondary sources of law such as maslahah mursalah. ${ }^{80}$ However maslahah mursalah is not mentioned specifically in the Qur'an or in the Hadith ${ }^{81}$

Maslahah literally means interest, welfare, advantage, wellbeing, and technically, it is meant to promote and bring welfare to the people and to avoid and prevent harm. ${ }^{82}$ Interest which it is qualified as maslahah mursalah refers to unrestricted public interest which is not regulated by the Law giver. In fact, there are three types of maslahah essential necessity (maslahah aldaruriyyah); general needs (maslahah al-hajiyyah); and embelishments (maslahah al tahsiniyyah). ${ }^{83}$

According to Kamali, "the essential masalih" ${ }^{84}$ are those on which the lives of people depend, and whose neglect leads total discipline of chaos". ${ }^{85}$ They consist of five essential values (aldaruriyyah al-khamsah) namely the religion (din), life (nafs), reason ('aql), lineage (nasb) and property $(m a l)^{86}$ Meaning that any

80 For the literatures on Maslahah Mursalah, See, Kamali, Principles of Muslim Jurisprudence, op. cit., pp. 351-368. See, Muhammad Akram Laldin, Introduction to Shari 'ah and Muslim Jurisprudence, (Kuala Lumpur, Malaysia: Cert Publications, 2006), pp. 108-110. See also, Michael Mumisa, Muslim Law Theory and Interpretation, (Beltsville, Maryland: Amana Publication, 2002), pp. 123-131.

${ }^{81}$ Tanzeem Fatima, Muslim Law and Judiciary, (New Delhi: Deep \& Deep Publications Pvt. Ltd., 2001), p. 1. See, Tauqir Muhammad Khan, Jurisprudence in Islam, (New Delhi: Pentagon Press, 2007), pp. 117-118. See also, Kamali, Principles of Muslim Jurisprudence, op. cit., pp. 354-355. See, Laldin, op. cit., p. 108.

82 Wan Azhar Wan Ahmad, Public Interest (Al-Masalih Al-Mursalah) in Muslim Jurisprudence: An Analysis of the Concept in the Shafi'i School, (Kuala Lumpur: the International Institute of Muslim Thought and Civilization, IIUM, 2003), p. 5-6. See, Wael B. Hallaq, An Introduction to Muslim Law (United Kingdom: Cambridge University Press, 2009), p. 25. See also, Kamali, Principles of Muslim Jurispurudence, op. cit., p. 351.

83 Imran Ahsan Khan Nyazee, Muslim Jurisprudence (Islamabad, Pakistan: the International Institute of Muslim Thought, 2000), pp. 199-200. See also, Mohammed Obaidullah, Ethics and Efficiency in Muslim Stock Market, <http:// phkumweb.ukm.my? hairon/kertas\%20kerja\%20assignment/Muslim\%20Stock\%Market.pdf>, accessed on 27 February2010.

${ }^{84}$ Masalih is the plural of maslahah.

${ }^{85}$ See, Kamali, Principles of Muslim Jurisprudence, op. cit., p. 356.

${ }^{86}$ Asyraf Wajdi Dusukiand NurdianawatiIrwani Abdullah, Maqasid al-Shari'ah and Corporate Social Responsibility, 〈http://www.kantakjie.com.figh/Files/Accountancy/0308914.pdf>, accessed on 23 December, 2009. See, Laldin, op. cit., p. 109, See also Kamali, Principles of Muslim Jurisprudence, op. cit., p. 351. See also, Wan Azhar Wan Ahmad, op. cit, p. 9. 
means to protect any one of the five values which be deemed as a maslahah in Islam.

Maliki, Hanbali and Hanafi jurists ${ }^{87}$ acknowledge maslahah mursalah as a valid source of juridical decision. They have set up guidelines and attached three conditions that should be fulfilled in applying the maslahah mursalah in transaction matters. The first condition is that the maslahah must be genuine (haqiqiyyah). A mere suspicion or specious conjecture (tawahhum) that a certain legislation will be beneficial without ascertaining the necessary balance between its possible benefits and harms is not sufficient. There must, in other words, be a reasonable probability that the benefits of enacting a hukm in the pursuance of maslahah outweigh the harms that might accrue from it.

Genuine masalih are those which contemplate the protection of the five essential values. The second condition is that the maslahah must be general in that it secures benefit, or prevents harm, from the people as a whole and not to a particular person or group of persons. The third condition is that the maslahahmust not be in conflict with a principle or value which is upheld by the nassor ijma', 88

Indeed, the concept of maslahah mursalah was applied in the ruling of the Prophet though, the Prophet did not use the term maslahah mursalah. ${ }^{89}$ When there is a Prophetic ruling in favour of maslahah it becomes part of the established law, and no longer a maslahah mursalah. Historically, the notion of maslahah mursalah originated in the practice of the companions. ${ }^{90}$ This is, of course, not to say that the Prophet did not rule in favour of maslahah but merely to point out that as a principle of jurisprudence, maslahah mursalah is part of the Sunnah.

\section{b. The Application of Maslahah Mursalah on the Manufacturing and Transboundary Movement of LMOs}

Manufacturing and transboundary movement of LMOs cannot be avoided in international trade. However, these activities are not regulated in the Qur' an and Hadisth. Nevertheless, the justification for these activities should be found in maslahah mursalah. The principle of maslahah mursalah can be used to justify the

\footnotetext{
${ }^{87}$ Abdul Hakim I. Al-Matroudi, The Hambalê School of Law and Ibn Taymiyyah Conflict or Conciliation, (New York: Routledge, 2006), pp. 78-80. See, Moch Safian and Yasmin Hanani, Islam and Biotechnology: With Special Reference to Genetically Modified Food, 〈http://www/metanexus.net/conference 2005/pdf/mohd_safian.pdf>, p. 10, accessed on 15 January, 2009.

${ }^{88}$ Laldin, op. cit., p. 110. See also, Kamali, Principles of Muslim Jurisprudence, op. cit., pp. 359-360.

${ }^{89}$ Kamali, Principles of Muslim Jurisprudence, op.cit.p. 354.

${ }^{90}$ Ibid.
} 
manufacturing, exporting and importing of LMOs. In this sense, maslahah mursalah protects both the interest of the exporting and importing states.

Therefore, maslahah mursalah cannot be used to abuse the right of other parties in manufacturing, exporting and importing of LMOs. For instance, maslahah mursalah cannot be justified for the sake and the interest of the exporters, while ignoring the interest of the importing states. Thus, in order to prevent the exporting states to accomplish their own unlawful intentions, the three conditions attached in the application of maslahah mursalah that have to be fulfilled.

Concerning the first condition, the interest in manufacturing and transboundary movement of LMOs in the form of GM crops should be genuine. For example, if the manufacturing and transboundary movement of LMOs in the form of transgenic crops are considered essential and are aimed at overcoming the hunger problem especially in the developing countries, maslahah mursalah can be adopted to justify the necessities of changing Allah's creation by using biotechnology and to validate the necessities of claiming legal ownership over such crops and food products. Thus, the activities are in line with the objective of protecting life, because providing food for the human being can be classified as protecting life.

Concerning the second condition, the interest of manufacturing and transboundary movement of LMOs in the form of GM crops should be general. In the sense that, the interest of the exporting states (the manufacturers) and the importing states should be accommodated. For example, the GM crops can be patented by the manufacturers. Thus, the manufacturers can exploit the poor country, as the seed of the crops has been patented. Therefore, when the farmers want to plant the crops, they have to buy the seed from the manufacturers. The condition may cause the farmers to be over-dependent on the manufacturers and they are going to lose their farming rights. Thus, the manufacturers can monopolise the price, and they will jeopardise the farmers' interest. If this kind of scenario occurs, the justification is not valid based on maslahah mursalah, because the advantages are only for a particular group of people (the manufacturers), while the other groups, such as, the consumers and the farmers in the importing states are neglected.

Concerning the third condition, the interest in manufacturing and transboundary movement of LMOs in the form of GM crops should be in accordance with the accepted sources of Shari' 'ah. It means that the manufacturing and transboundary movement of LMOs should not contradict with the Qur'an, Hadith, Qiyas and 
Ijma.${ }^{91}$ For example, the DNA which is used to create GM crops has to use a certain kind of DNA which is notharam. Thus, the crops is justifiable based the accepted sources of Shari'ah. It follows, if the need to fulfil the people in Muslim States is classified as necessities, because it cannot be substituted by other varieties of crops. Hence, the manufacturing, exporting and importing of GM crops can be categorised as necessities food for people (daruriyyah) which are absolutely indispensable needs to preserve the life.

Prophet is reported to have said that "Muslim are bound by their stipulations unless it be a condition which turns a haram into halal or halal into haram". ${ }^{92}$ This would seem to be granting Muslims the liberty to pursue their benefits and to commit themselves to that effect provided that this does not amount to a violation of explicit commands or prohibition of Shari ${ }^{`} a h .{ }^{93}$

Accordingly, if the manufacturing, exporting and importing of LMOs cannot be classified as maslahah daruriyyah or hajiyyah, this matter may be prohibited by the states, since, there may be some adverse impacts of the LMOs in the long run which is not certain, and the PP should be applied. It follows that the interest should be one of the essential (daruriyyah) or the necessity (hajiyyah) and not of the perfectionist (luxury, tahsiniyyah) type, because the intention of maslahah tahsiniyyah is not crucial to protect the life.

\section{c. The Application of Maslahah Mursalah Regarding the Issue of Changing Allah's Creation}

Islam, at the first stage regards attempt to modify living things a sin as stated in the Qur'an:

Allah did curse him, but he said: "I will take of Your servants a portion marked off, I will mislead them, and I will create in them false desires, I will order them to slit the ears of cattle, and to deface the (fair) nature created

${ }^{91}$ Ibid. See, Shaikh Mohd Saifuddeen, Religious Sector Keeping Faith in the Technology, <http://www.isaaa.org/resources/publications/briefs/40/download/isaaa-brief-402009-religious-sector.pdf $>$, accessed on 22 May 2010. See, Kamali, Principles of Muslim Jurisprudence, op. cit, pp. 359-360, See also, Laldin, op. cit, p. 110.

92 Sunan Abū Dāwud, Book III, 1020, Hadith no. 3587. Islamsoft-Solution, the Future Toward Universe of Revolutionised Software, <http://www.islamsoft.co.uk $>$ accessed on 12 February, 2010.

Economics,

${ }^{93}$ Muhammad Yusuf Saleem, Methods and Methodologies in Fiqh and Muslim <http://www.muslimcenter.kau.edu.sa/English/English20Papers\%5B21\%sD\%20M.Yusuf\%20s aleem.pdf $>$, accessed on 16 February, 2010. 
by Allah." Whoever forsaking Allah, takes Satan for a friend, hath a surety suffered a loss that is manifest. ${ }^{94}$

This verse is a warning from Allah that any means to unnecessary change of the creation of Allah will make one subject to the curse of Allah. However, if the change falls under the category of essential type (daruriyyah), so such a change and modification is permissible. For instance, if the genetic engineering is conducted to prevent harm such as to reduce reliance on pesticides and herbicides, which damage the environment, such a demeanour is permissible and is in line with the principle of Shariah that is promoting welfare and preventing harm. ${ }^{95}$

Besides that, in order to create better livestock and crops, Islam does encourage gene modification that has been used for centuries using natural methods involving organisms of the same species. There is a Hadith where the Prophet approved the action of crossbreeding of dates plants by the Arab in his saying: "You are more knowledgeable in your worldly affairs". ${ }^{96}$ However, according to this hadith that was narrated by Anas, at the first stage, when the Prophet saw the Arabs were making crossbreeding into the dates plants, he prohibited them by saying that it was better if they let the dates grow naturally.

Nonetheless, when the Arabs let the dates grow naturally as suggested by the Prophet (p.b.u.h), the yield of the plant was not as satisfactory as before. In the same Hadith the Prophet (p.b.u.h) mentioned that he was the best person to refer to in religious matters. Conversely, when it comes into the worldly affairs, such as the breeding system, he admitted that the farmers knew better than him. This is evident that Islam does not put strict limitation in worldly affairs. The plants can be used, managed and utilised for the benefit of the common people.

Therefore, observing the said Hadith, it is evident that at the first stage the Prophet preferred to preserve and dominate living things in their natural ways. However, if there is a need to modify them in natural ways such as crossbreeding or what so ever for the good of human life, he did recognise such an action. It is submitted that the principle of maslahah mursalah may be applicable to justify the necessity of changing Allah's creation in GM technology.

In fact, the changing of Allah's creation from conventional crops to be GM crops is not free from adverse impacts, because

94 See, the Qur'an. 4:119

${ }^{95}$ Safian and Hanani, op.cit., p. 75.

${ }^{96}$ Hadith.Sahih Muslim. No. 4358. Islamsoft-Solution, the Future Toward Universe of Revolutionised Software, 〈http://www.islamsoft.co.uk〉, accessed on 27 January, 2010. 
GM crops have inherent risks. Humans introduce new genetic material to the gene pool. It is unclear what the long-term consequences will be of placing new species of plants into the environment. It is possible that these species will pass their genetic material to other plants, mutate, or hybridise, such as super weeds. Consequently, the new species cause pollution to biodiversity.

Thus, PP should be applied in manufacturing of LMOs both in the form of GM crops and GM food. The application of PP which can be applied in states level is in line with the maslahah mursalah, because based on PP states have obligations to protect public interest, namely: public health and sustainable used of biodiversity. However, if genetic engineering is conducted to prevent harm such as to reduce reliance on pesticides and herbicides which damage the environment, ${ }^{97}$ such a conduct is allowable. Thus, the change falls under the category of essential type (daruriyyah), so such a change and modification is permissible. ${ }^{98}$

In fact, the justification of using biotechnology to manufacture GM crops can be found in the seminar on "Genetics, Genetic Engineering, the Human Genes, and Genetic Treatment An Islamic Perspective" which was held by Fiqh Academy, Jeddah and Islamic Education, Science and Culture Organisation, in Kuwait in 1998. ${ }^{99}$ In the Seminar, the following principles were approved by all of the Participants of the Seminar: (i) Any tempering with man's basic constituents would be in violation of man's God given dignity; (ii) Islam is religion of knowledge and science, which imposes no restriction on constructive scientific research. Thus, Islam supports genetic engineering; (iii) Nobody's genes should be subject of research without evaluating its pros and cons; (iv) No research of human genes or application of any such research should take precedence over the Shari'ah and the respects of human rights, basic liberties and human dignity of any individual or group of individuals; (v) The reading of human genes by mapping out the full genome is part of man's endeavour to understand Him and appreciate God's power of creation. It is important from medical point of view also; (vi) Genetic engineering may be used in the prevention, treatment or alleviation of diseases. Genetic engineering should not use stem germ cells (for example stem cell of premature fetus); (vii) Genetic engineering should not be used for any sinister or offensive purposes, or crossing the genes merely

\footnotetext{
${ }^{97}$ Ibid.

98 Latifah Amin, et. al., Muslim Ethics and Modern Biotechnology, <http://www.Sarionline.ukm/SARI\%2027(2)/SARI27\%5B2\%5D2009\%20\%5B13\%5D.pdf>, accessed on 26 February, 2010. See also, Safian and Hanani, loc. cit.

99 Islam Set, Science, Environment and Technology, Seminar on Genetics, Genetic Engineering, the Human Genes, and Genetic Treatment-AnMuslim Perspective, Kuwait, 1998, <http://www.Islamset.com/biothics/genetics/genetics.html>, accessed on 10 February, 2010.
} 
for sport or scientific curiosity; (viii) Genetic engineering must not be used for changing the human structure; (ix) The poor should also benefit from scientific researches; (x) Islam does not object to the use of genetic engineering in the fields of agriculture and livestock, without ignoring those voices that have recently warned of possible harmful long-term effects on man, animals, crop or the environment.

Thus, the manufacturing of LMOs should comply with the Islamic teachings on environment and the total harmony between the man and other creations should be maintained. One of the instruments to maintain the harmony between man and the other creations is PP, because there is also interdependency among creations of Allah. ${ }^{100}$ According to , there is no possibility of living in isolation from science and its products, though the harm that it does may be greater than the good. There is no such thing in this life as an unmixed blessing or an unalloyed evil. Islam does not oppose science or the utilisation of science; there is nothing contrary to the spirit of Islam in culling the fruits of science from all the sources of the world. ${ }^{101}$ Thus, Muslim states as Members of the WTO cannot prohibit the manufacturing, exporting and importing of GM crops and GM food from other countries when all the products comply with all of the requirements of Islamic Law.

\section{d. Being Lawful (Halal) and Being Good (Tayyib) as the Requirements of Transboundary Movement of LMOs to the Muslim States}

The manufacturing, export and import of LMOs directly used as foods or introduced to the environment have to comply with the requirements of being lawful (halal) and being good (tayyib). ${ }^{102}$ It means that the manufacturing of the LMOs itself must not use DNA derived from species which is unlawful (haram) to be consumed, such as pig. So, if some varieties of plants which are not developed from DNA of pigs but from micro organisms and fish, then such kinds of varieties of plants are not haram.

Although the DNA derives from halal species, if the varieties of plants may cause adverse impacts to human health, they are not tayyib. Being tayyib is one of the conditions that should be satisfied for food production and the manufacturing of plant varieties, because the plants will produce products that will be consumed by human beings that may affect the human health in the future. Thus,

100 See, the Qur'an, $3: 19 ; 21: 16 ; 44: 38 ; 25: 2,87: 3 ; 80: 19 ; 13: 9$. See also, Ansari and Jamal, op.cit, , at 85 .

${ }^{101}$ Sayyid Qutb, Social Justice in Islam, trans. John B. Hardie, trans. rev. Hamid Algar, (Kuala Lumpur: Muslim Book Trust, 2000), p. 288.

102 See, the Qur'an, 2:168. 
the manufacturers have to comply with the requirements established by the Halal Food Council International (hereinafter HFCI). The governments in Muslim states have an obligation to protect the public interest (maslahah mursalah) ${ }^{103}$ such as, by banning and phasing out harmful products as the forms of precautionary measures.

\section{e. Being Lawful (Halal)}

The word "halal"is associated with the word "tayyib" which means 'good'. halall is an Arabic word which means 'lawful, legal, licit, legitimate, permissible, allowable, permitted, allowed, admissible, authorised, unprohibited, unforbidden or unproscribed'. ${ }^{104}$ From the Islamic perspective,halalmeans anything or act that is permitted and allowed by Allah. ${ }^{105}$

Allah commands human being to eat of the lawful (halal) and good (tayyib) things which Allah has provided. ${ }^{106}$ According to Halal Accreditation, ${ }^{107}$ there are several factors that determine the halal/haram status of a particular foodstuff. ${ }^{108}$ Amongst others, it is dependent on its nature, how it was processed and where it originated from. As an example, any pig product is considered haram because the material itself isharam. ${ }^{109}$ Whereas beef from an animal that has not been slaughtered according to Islamic rites would still be considered haram. ${ }^{110}$ Moreover, haram is food that has been stolen or acquired through unethical means. Islam also prohibits the usage of any materials that are detrimental to the spiritual or mental well-being of a person, such as alcoholic drinks and drugs. ${ }^{111}$

On the other hand, in the recent development of food intake, hala consists of anything that is free from any component that

103 According to Khalid: "The primary duty of the Muslim States is to promote the good and forbid wrongdoing. As part of these functions, it has the mandate to protect land and natural resources from abuse and misuse." Khalid, op.cit,p. 9. See also, Ali Ahmad, op.cit, p. 59.

${ }^{104}$ Association of American Halal "Halal Defined,"'http://aahalalcert.org/halalDefined.htm, accessed on 2 January, 2011. See, Muslim Glossary, "Muslim Glossary and Expression,"http://www.calltoplayer.info/id4.html,accessed on 20 October, 2010. See also, Wikipedia, Muslim Dietary Law, <http://www.ask.com/wiki/Muslim-dietary_laws?qsrc=3044> accessed on 20 October 2010.

105 London Borough of Hackney, London Central Mosque \& the Muslim Culture Centre, A Food Guide for Muslim Trader, <http://www.iccereives.org.uk/downloads/halalleaflet/halal-trader-s-eng.pdf $>$, accessed on 24 December, 2010.

${ }^{106}$ See, the Qur'an, 16: 114 and the Qur'an, 5:88.

${ }^{107}$ AFIC Schools, Halal General Definition, <http://www.afic.com.au/?p=405>, accessed on 21 December, 2010.

${ }^{108}$ Ibid.

109 See the Qur'an. 5: 3.

${ }^{110}$ Ibid.

111 See the Qur'an. 5: 90. 
Muslims are prohibited from consuming. In this era of technology, the concept of halal can no longer be restricted to simply meaning food that is "pork free" in its physical existence. ${ }^{112}$ It covers a multitude of forms such as emulsifiers and other food substances such as gelatine, enzymes, lecithin, and glycerine as well as additives such as stabilisers, flavouring, colouring, breadcrumbs etc.

On the other hand, haram is an Arabic word which means 'prohibited, interdicted, unlawful, illegal or banned'. ${ }^{113}$ The Qur'anic term haram is that which is absolutely prohibited by Allah (S.W.T.). With regard to haram, there are absolute restrictions of consumption and use in normal circumstances. Anyone who engages in haram $^{114}$ is liable to punishment of Allah (S.W.T.) in the Hereafter, and in some specific cases, in this world. There are four types of food which are clearly haram things, namely: carrion; blood; swine flesh; and that which hath been immolated to (the name of) any other than Allah. ${ }^{115}$

GM food and GM crops which are considered as new products are not directly regulated by the Qur'anorHadith. However, if the products are consumed by the citizens of the Muslim states, the products should be lawful (halal) and good (tayyib) in accordance with the Islamic law. Thus, for GM crops and GM food to be accepted as halal crops and halal food, they should gain certification from the government, as practiced in Malaysia, Indonesia and Singapore. ${ }^{116}$ States have respectively established an

112 Ahmad Hidayat Buang and Zalina Zahara, Tapping into the World Halal Market: Some Discussions on Malaysian Laws and Standards, "Shariah Journal", Vol. 6., Special. Edition (2008), pp. 603-616, <http://myais.fshtm.um.edu.my/9595/I/TAPPING_INTO THE_WORLD_HALAL_MARKET _SOME_DISCUSSIONS_ON_MALAYSIAN_LAWS_AND_STANDARDS.pdf $>$, accessed on 29 December, 2010.

113 Muslim Society of North America, Halal Product, <www.nussack.com/finemeat/halal.php>, accessed on 23 December, 2010. See also, Halal Certification Services, What is Haram?, <http://swisshalal.ch/archives/72>, accessed on 22 December, 2010.

${ }^{114}$ See, the Qur'an, 6: 145.

Allah(s.w.t) commands His prophet Muhammad (s.a.w) that:

Say: I do not find in what is revealed to me, anything forbidden to one who eats of it unless it be dead meat, or blood poured forth or the flesh of swine,-for it is impious, (meat) on which a name has been invoked, other than Allah's". But (even so), if a person is forced by necessity, without willful disobedience, nor transgressing due limits,- Thy Lord is forgiving, Most Merciful.

See also, the Qur'an 2: 173.

115 See the Qur'an, 2: 173 and the Quran. 5: 3.

See also, H.A.Fahim, GMO Product from the Muslim Perspective: Are They Halal (Lawful) or Haram (Unlawful)?, IFT Annual Meeting, July 15-20, 2005, New Orleans, Louisiana.

116 HalalFood Council SEA, Certification Requirements, <http://halalfoodcouncil.info/certification requirement.html>, accessed on 26 December, 2009. 
institutional body in the government which is in charge of the certification of halal food, in order to protect public interest (maslahah mursalah).

For instance, in Malaysia halal food certification refers to the examination of food processes in its preparation, slaughtering, cleaning, processing, handling, disinfecting, storing, transportation and management practices. The application of halal should apply to all stages of processing "from farm to table." 117 Indeed, this process reflects the application of precautionary measures in issuing certification for halal food.

Thus, these kinds of conditions are also compatible with the PP, since the requirements include the quality assurance of food. This is to guarantee that these products are halal and tayyib to be consumed for the Muslim population. Halal and non-halal things cover all aspects of Muslim life; not only limited to foods and drinks. Halal and tayyib themselves portray the symbol of intolerance in hygiene, safety and quality. ${ }^{118}$ According to the Department of Islamic Development Malaysia/Jabatan Kemajuan Islam Malaysia (hereinafter JAKIM). In order to gain halal certification, manufacturers must adhere to strict cleanliness and quality controls. ${ }^{119}$

In addition, to meet the halal requirement, food producers are encouraged to adapt and maintain standards that meet global benchmarks such as ISO 9000, Codex Alimentarius, Quality Asurance (QA), Hazard Analysis Critical Point Control (HACCP), Good Hygienic Practice (GHP), and Sanitation Standard Operating Procedures (SOPs), and halal certification. ${ }^{120}$ Thus, the halal issues are in conformity with safety and quality assurance. It means the product prepared must be up to the standards, which also include hygiene. Safety and quality assurance ensure that the halal products are also clean, safe and well taken care of, with good

\footnotetext{
117 Jabatan Kemajuan Islam Malaysia $\quad$ (JAKIM), <http://Halaljakim.gov.my/corporate.html>, accessed on 12 January, 2010. Abdalhamid Evans,

Are Muslim Eating Halal in Canada?,
<http://www.shiachat.com/forum/index.php?/topic/234920695-eating-halal-in- canada?>, accessed 24 January, 2011. See also, Muslim Society of North America, op. cit.

118 Hayati Habibah, et. al., Quality Assurance in Halal Food Manufacturing in Malaysia: A Preliminary Study, Proceedings of International Conference on Mechanical \& Manufacturing Engineering (ICME2008), 21-23 May 2008, Johor Bahru, Malaysia. Faculty of Mechanical \& Manufacturing Engineering, University Tun Hussein Onn Malaysia (UTHM), Malaysia.

119 JAKIM, op.cit., p. 105.

120 Halal certification must become an efficient, transparent and industry-compliant procedure. There is no reason for the audit and certification process to be any less professional than in any other facet of the food industry, or any other industry for that matter. See, Halal Market Consultant, Halal Market Analysis, Halal Market Intelligence Newsletter, $\langle$ http://halalfocus.com/artman2/uploads/1/Halal_market_intelligence_news_may_07. pdf $\rangle$, accessed on 22 December, 2010.
} 
presentation and served in a proper manner, and of quality for everybody. Thus, all stages of preparation, processing and storage must be under direct supervision of a Muslim who is competent and knowledgeable in halal dietary laws.

With the certification, manufacturers are obliged to act responsibly to maintain the halal status of the food they produce. Manufacturers must ensure during all phases of the production, the raw materials, equipment, tools and materials used must not be najs (filthy), mixed with any najs material or has been in contact with najs materials. ${ }^{121}$ The product and raw materials used must also be safe and must not cause harm to human and animal health (tayyib). Hence, the requirements are also applied for the manufacturing of GM crops and GM foods.

Ensuring a product is halal is not only limited to the materials and ingredients used. ${ }^{122}$ Halal requirements cover all aspects of preparation, processing, packaging, distribution and all related processes. Any equipment found to be in contact or contaminated with non-halal materials must be cleansed according to the Shari 'ah requirements. This is an important prerequisite for halal certification and the requirement covers personal hygiene, attire, equipment and working environment. ${ }^{123}$

One of the consensus (ijma') that have been established is the guidance of halal food endorsed in the Codex Alimentarius. In fact, the guidance has been adopted by HFCI. It is the halal certifier operating in the United States. HFCI got recognition from JAKIM (Malaysia), MajelisUlama Islam Singapura and MajelisUlama Indonesia under the name of Halal Food Council South East Asia (HFC-SEA). HFC-SEA's main business is to certify meat and meat products in the United States. HFCI strictly follows the guideline of halal as set by Malaysia, Singapore and Indonesia. ${ }^{124}$ This guideline appears in the Codex Alimentarius (1997) that has been approved by all Muslim states in the world. This includes the standard of halal slaughter, halal food, halal cosmetics and halal usable goods.

According to Halal Food Council International, Halal food means food permitted under the Islamic Law and should fulfil the following conditions: (i) It must not consist of or contain anything which is considered to be unlawful according to Islamic Law; (ii) It must not have been prepared, processed, transported or stored

\footnotetext{
121 Nurliza Ramli, The New Global Trade Force, 〈http://www.lexmundi.com/images/lexmundi/PDF/Skrine-NR.pdf $>$, accessed on 29 December, 2010 .

122 London Bourogh of Hackney, London Centre Mosque \& the Muslim Cultural Centre, op. cit., at 97.

${ }^{123}$ Habibah, et. al., op. cit p. 110.

${ }^{124}$ HalalFood Council SEA, op. cit., p. 108.
} 
using any appliance or facility that was not free from anything unlawful according to Islamic Law; and (iii) It must not, in the course of preparation, processing, transportation or storage, be in direct contact with any food that fails to satisfy the requirements which are established in Islamic Law. ${ }^{125}$

Thus, the halal guidance which is adopted by the HFCI can be deemed as an instrument to take precautionary measure to guarantee that LMOs which is manufactured is lawful, because the conditions that must be fulfilled to comply with the halal guidance include the raw materials and also the process of production. It is submitted that the LMOs can obtain halal certification, if they comply with all the requirements.

\section{f. Being Good (Tayyib)}

According to Islamic law, certain kinds of food products and also plant varieties that will be marketed must be halal and tayyib. Thus, it is not sufficient if the products are only halal but not tayyib. In the case of LMOs, the manufacturing of LMOs by using biotechnology is not against the Shari'ah, if the products which come from the LMOs are halal to the extent that not haram considering both the process and the products. ${ }^{126}$

In line with the Islamic dietary law, most foods and drinks are considered haläl except those which have been prohibited in the Qur'an ${ }^{127}$ or the authentic Hadith. ${ }^{128}$ Islam requires people to eat what is lawful and good. This ordainment is stipulated in the Qur'an as follows: "O mankind! Eat of that which is halal and tayyib on the earth ...." ${ }^{129}$

In the above mentioned verse, the word good (tayyib) is being associated with the word lawful to emphasise the importance of wholesomeness in food. The Qur'anic phrase "lawful and good

\footnotetext{
125 Muslim Society of North America, op. cit., p. 105.

126 AFIC School, Halal Services, Halal Acreditation, Muslim Australia, Halal-General Definition, 〈http://www.afic.com.au/3=Q65 >, accessed on 30 March, 2010.

127 The Qur'an, 2: 173.

128 Abu Hurairah, radilallahu 'anhu, reported that the Messenger of Allah, sallallahu 'alayhiwasallam, said:

" Verily Allah the Exalted is pure. He does not accept but that which is pure. Allah commands the believers with what He commanded the Messengers. Then he (the Prophet) mentioned (the case of) the man who, having journeyed far, is dishevelled and dusty and who stretches out his hands to the sky (saying): "O Lord! O Lord!" (while) his food was unlawful, his drink was unlawful, his clothing was unlawful, and he is nourish with unlawful things, so how can he be answered"?

See, Hadith Sahih Muslim, Hadith 10, No: 1015. Nawawi.s Collection of 40 Hadithon Video, http://muslimtube.net/search_result.php? search_id=Nawawi=Hadith\&dtk_searchsubmit.x=0\&dtk_searchsubmit. $y=0 \&$ search_typ $=$ serac h_videos, accessed on 25 November, 2010.

129 The Qur'an.2:168 and the Qur'an. 23: 51.
} 
(tayyib)" in the verse signifies that from Allah's perspective, all halal products must also be necessarily good (tayyib). In other words, it carries the notion of wholesomeness of the products so that their consumption may lead to the well-being of mankind in general. According to the Islamic Society of America, the food to be good (tayyib) for consumption has to fulfilled two conditions, namely: (i) the food must be wholesome and nutritious; and (ii) the food must be safe for consumption. ${ }^{130}$

Emphasis should be on primary production, which should be carried out in an area where the presence of potential harmful substances does not contaminate the food until it reaches an unacceptable level. The fundamental thing is that hygienic practices should reduce the likelihood of introducing hazards which may adversely affect the safety of foods at later stage of the food chain. ${ }^{131}$ For example, hazards from pesticides, antibiotics or microorganisms. Of course, this condition also applies to the GM crops which include the DNA that will be inserted to the conventional crops whether from animals or microorganisms which has to be tayyib. Therefore, if DNA is taken from animals which are tayyib according to Islamic law, the GM crops will be tayyib. ${ }^{132}$

Thus, in the case of GM crops and GM foods which comply with the conditions of Islamic dietary law, these products are lawful (halal) and good (tayyib). Due to the fact, that there is no further explanation for the new technologies such as LMOs in the Qur'an and Hadith jurists may have to regulate them as far as their justifications are in line with public interest (maslahah mursalah) and the objectives of Islamic Law. ${ }^{133}$

The Qur'an has laid down several rules on food intake. Allah the Almighty says: "Eat of the things which Allah has provided for you, lawful and good: But fear Allah, in Whom ye believe". ${ }^{134}$ From this verse, it is clear that Allah orders us not to only eat halal food, but good (tayyib) food as well. Thus, based on this verse, human beings should not only avoid unlawful (haram) foods and drinks such as non-slaughtered animals and liquor, but should also bear in mind not to consume food which jeopardizes their health. Thus, being tayyib is in accordance with the PP, because tayyib includes the requirement of good quality of food which does not have adverse impacts to the human health. ${ }^{135}$

\footnotetext{
${ }^{130}$ Muslim Society of North America, op. cit., p. 105.

131 London Bourogh of Hackney in Partnership with London Centre Mosque \& the Muslim Cultural Centre, op.cit.,p. 97.

${ }^{132}$ LatifahAmin, et.al., op. cit, p.88.

133 Evans, loc. cit.

134 The Qur'an, 5:88 and the Qur'an, 23: 51.

135 Kari Ansari, IFANCA: Leader in Promoting Halal to America's Consumers, $<$ http://americanhalalassociation.org/AHA/HalalConnect_files/HalalConnect $\% 20$ Binder\%20.pdf>, See also, Buang and Zahara, op. cit. p. 614.
} 
Hence, with the increase in the manufacturing and exportation of LMOs, the importing states should ensure that the GM crops and GM foods that they import are halal and tayyib. There are many research works and experiments that have been conducted which concluded that GM foods are as safe as their conventional counterparts. However, further studies by WHO which are discussed in chapter three demonstrates that there are potential negative effects of GM food to human health. In a similar vein, it was concluded that GM crops also have negative impacts on the environment. Therefore, states which have the authority to protect the public health and the environment, including the biodiversity, have an obligation to ensure that the GM crops and GM foods are halal and tayyib, in the sense that, that they are safe for human consumption and will not pollute or pose any threat to the biodiversity.

\section{PERMISSIBILITY OF PRECAUTIONARY PRINCIPLE BASED ON SADD AL-DHARA'I}

PP is not explicitly defined in Islamic teaching of environment, however, the notion of PP can be found in a secondary source of Islamic Law, namely: sadd al-dhara'i signifies the means to obtaining a certain end, while sad literally means "blocking". ${ }^{136}$ Sadd al- dhara' $i$ thus implies blocking the means to an expected evil which is likely to materialise if the means towards it is not obstructed. ${ }^{137}$ In its juridical application, the concept of sadd al-dhara' $i$ also extends to "opening the means to beneficence". ${ }^{138}$

When the means and the end are both directed toward beneficence and maslahah and are not explicitly regulated by a clear injunction (nass), the matter is likely to fall within the ambit of qiyas, maslahah, or istihsan. ${ }^{139}$ Similarly, when both the means and the end are directed towards evil, the issue is likely to be governed by the general rules of Shari'ah, and a recourse to sadd al-dhara' $i$ would seem out of place. However, the Muslim jurists are in disagreement over the validity of sadd al- dhara'i. ${ }^{140}$

136 Kamali, Principles of Muslim Jurisprudence, op.cit,p. 397. See.Laldin, op.cit.,p. 112.

137 Muhammad Yusuf Saleem, op.cit. at 81.

${ }^{138}$ Kamali, Principles of Muslim Jurisprudence, no.2, p. 397. See also, Mawillzzi Dien, Muslim Law from Historical Foundations to Contemporary Practice, (Edinburgh: Edinburgh University Press, 2004), p. 63.

139 Kamali, op.cit., p. 397.

140 The Hanafi and Shafi'i jurists do not recognise it as a principle of jurisprudence in its own right, on the grounds that the necessary ruling regarding the means can be derived by recourse to other principles such as qiyas, and the Hanafi doctrines of istihsan and 'urf. But the Maliki and Hanbali jurists have validated sadd al-dharE' 'iN as a proof of Shari'ah in its own right. Despite the different approaches that the Muslim jurists have taken to this doctrine, the 
Based on this analysis, it would appear that as a principle of jurisprudence, sadd al-dhara'I applies when there is an inconsistency between the means and the end on the good-neutral-evil scale of values. A typical case for the application of sadd al-dhara'i would thus arise when a lawful means is expected to lead to an unlawful result, or when a lawful means which normally leads to a lawful result is used to procure an unlawful end. ${ }^{141}$

Indeed, sadd al-dhara' $i$ as a PP in Islamic perspective is founded on the idea of preventing an evil before it actually materialises. ${ }^{142}$ It is therefore not always necessary that the result should actually be obtained. According to Ibn al-Qayyim, sadd al-dhara' $i$ is one-fourth of the Shari'ah. He divides the whole Shari'ah into two parts, namely order and prohibition. ${ }^{143}$ An act is ordained because either it is desirable in itself or it is a means to securing a desired object. Similarly, a thing liable to prohibition is prohibited in itself or because it may be a means to indulgence in prohibited thing, in which case its prohibition is a precautionary measure. ${ }^{144}$

From the viewpoint of the degree of probability or otherwise that a means is expected to lead to an evil end, the jurists of $u s u l$ have divided the dhara' $i$ into four types: ${ }^{145}$

a) Means which definitely lead to evil. Such means are totally forbidden.

b) Means which are most likely to lead to evil and rarely leads to benefit. Examples of this are selling weapons during war time and selling grapes to a wine-maker. Most jurists have invalidated such means.

c) Means which frequently lead to evil, but there is no certainty or even dominant probability. ${ }^{146}$ Jurists differ widely on the legality of such means.

Maliki jurist al-Shatibi has reached the conclusion that the Muslim jurists of various schools are essentially in agreement over the conceptual validity of sadd al-dharÉ 'iN but have differed in its detailed application. Ibid. p. 401.

${ }^{141} \mathrm{Al}$ Eddine Kharoufa, Philosophy of Muslim Shari'ah and Its Contribution to the Science of Contemporary Law, 〈http://muslimstudies.islammessage.com/panel/media/philosophy-of-Muslim-Shariah.pdf >, accessed on 3 February, 2011.

${ }^{142}$ Shah Abdul Hanan, Usul Al Fiqh (Muslim Jurisprudence), <http://www.bandung2. co.uk/books/files/hw/usul\%20Al-Fiqh\%20\%20Abdul\%20Hamman.pdf >, accessed on 3 February, 2011.

143 Abdul Azim Islahi, Economic Thought of Ibn Al Qayyim, King Abdulaziz University, International Centre in Muslim Economic, <http://www.hantakji.com/fiqh/Files Economics/c433.pdf>, accessed on 4 February, 2011.

144 Ibid.

145 Yasin Dutton, The Source of Muslim Law, <http://www.muhajabah.com/clocstorage/dutton.htm>, accessed on 4 February, 2011. 
d) Means which rarely lead to evil. ${ }^{147}$ Jurists have ruled in favour of permissibility of these means.

Thus, sadd al-dhara'i especially the third and fourth type of dhara' $i$ which is explained above is not contrary with PP. It can be used as a justification to conduct precautionary measures on transboundary movement of LMOs and the manufacturing of LMOs, because the concept of sadd al-dhara' $i$ is established on the idea of deterrence of evil before it occurs. It is submitted that the third and the fourth types of dhara' $i{ }^{148}$ is the most appropriate to deduce the legal basisof permissibility of PP in Islamic Law.

For example, if LMOs which are directly introduced into the environment can be deemed as means in the doctrine of sadd al-dhara' $i$ , whereas adverse impacts which are caused by LMOs can be deemed as ends, thus the application of sadd al-dhara'i can be justified. In this circumstance, the means itself is lawful, but the end may be unlawful, because there is probability of harmful impacts to the human health and the environment. In fact, there is a dominant probability that the manufacturing and introducing LMOs into the environment would lead to adverse impacts of human health and environment, although there is an element of uncertainty. It should bear in mind that the basic norm in regard to manufacturing and introducing LMOs into the environment are generally lawful, this basic legality is of no consequence if it is expected to procure an evil. Furthermore, preventing the evil must be given priority over any possible benefit that the manufacturing and the introducing of LMOs into the environment in question might entail.

It follows that the means must conform to the ends (objectives of Shari' $a h$ ) and ends must prevail over the means. If the means violate the purpose of Shari'ah, these must be blocked. Therefore, PP which is applied on transboundary movement of LMOs actually is intended to

146 For example, people use legally correct contracts with hidden tricks as means to usury. According to Maliki and Hambali jurists agreed to block the means, while other disagreed because the harm is not certain or most probable. See, Jasser Auda, Maqasid AlShari'ah As Philosophy of Muslim Law, (London: the International Institute of Muslim Thought, 2008), p. 127. See also, Mohammad Hashim Kamali, Muslim Commercial Law an Analysis of Futures and Options, (Kuala Lumpur, Malaysia: Ilmiah Publishers, 2002), pp. 2526.

${ }^{147}$ Jasser Auda, op. cit., p. 126. An example of an action that result in a "rare harm", according to al-Shatibi is selling grapes, even though a small number of people will use them to make wine. See also, Laldin, op. cit., p. 114. Example of rare harm, such as, the usage of computer of telecommunication devices may have probabilities to lead crimes.

148 The third of the four types of means under discussion is that which frequently leads to evil, but in which there is no certainty, nor even a dominant probability, that this will always be the case. An example of this would be a sale which is used as a means to procuring usury (riba). These types of sales, generally known as buyu' al-ajal (deferred sales), in which either the delivery of the object of sale, or the payment of its price, is deferred to a later date, would all tend to fall under this category of means. See, Kamali, Principles of Muslim Jurisprudence, op. cit, p. 402. See also, Yasser Auda, op. cit., p. 126. 
protect public interest, because protecting environment and human health from adverse impact and serious threats of LMOs can be classified as public interest. Protecting of public interest is recognised as maslahah mursalah in Islamic Law.

The notion of PP, which is more concerned to the authority of states to take precautionary measures to protect human health and environment when there is scientific uncertainty is permissibility based on sadd al-dhara' $i$. Besides that it is in conformity with the principle of maslahah mursalah (public interest). ${ }^{149}$ Indeed, the principle of maslahah mursalah is based on the principle of avoiding harm and promoting interest.

The common numerous tools for carrying out PP, such as bans and pre-market or pre-activity testing requirements of the products are aimed at protecting the public health and the environment which includes the biological diversity to prevent the adverse impacts of LMOs. Thus, the PP encourages states to take precautionary measures, highlights the role of states to achieve SD and to maintain the intergenerational equity. ${ }^{150}$ Indeed, the PP as one pillar of SD is in accordance with Islamic principles, because human is only guardian of nature. Islam strongly advocates the intergenerational equity and SD.

The concept of SD which has close relationship with the intergenerational equity principle has been endorsed in Islamic teaching of environment. As a trustee, man has a duty to make a harmonious relationship with the nature. ${ }^{151}$ Hence, man has to manage the nature in accordance with the purpose intended by its Creator which is to utilise it for his own benefit and other created beings, and for the fulfilment of his interest and of others. ${ }^{152}$ This duty definitely demonstrates the idea of intergenerational equity, which demands sustainable use of natural resources. If human beings do not use the natural resources in sustainable manner, they cannot offer anything to the future generations.

Therefore, human has violated the Allah's command, such as, to maintain the balance of the environment. In Islam, human are expected to protect the environment since no other creatures is able to perform this task. Humans are the only being that Allah (S.W.T.) has entrusted

149 The main source of hukm (legal rules) in Islam is al-Qur'an and tradition of the Prophet (al-hadith), consensus and analogy. However, if the problem is not covered textually, the principle of public interest (maslahah mursalah) may be applied into the matter. See, Laldin, op. cit., p. 108.

150 Ansari and Jamal, op. cit., pp. 86-87. See also, Tony Cisse, Islam, the Environment and the Use of Vetiver Grass, <http://www.fetiver.org/SEN-Cisse2.pdf>, accessed on 5 January, 2010.

${ }^{151}$ See, the Qur'an, 87:2.

152 Niaz Ahmed Khan, Sustainable Development and Muslim Ethics: A Primer on the Conceptual Linkage, $\quad$ http://www.Viewsontourism.info/worpross/cupcontext/uploads/2010/03/Sustainable_development_and_Muslim_Ethics_by_Dr-Niaz-AhmedKhan.pdf>, accessed on 4 June, 2010. 
with responsibility of looking after the earth. ${ }^{153}$ This trusteeship is seen by Islam to be so onerous and burdensome that no other creature would accept it.

Besides that, Islamic teaching of environment also recognises that nature is common heritage of mankind, thus in the context of international trade, states have an obligation to protect and to preserve the environment from harm and deterioration which is caused by international trade such as the export and import of LMOs. Islam calls for moderation in the development of natural resources. ${ }^{154}$ Therefore, states should be moderate in behaviour, value judgement and keep modesty in making use of the natural resources which embodies in its perception and beliefs, in organisation, and in the relationship of the states to individual to the community and to the environment.

Hence, the PP is in accordance with the Islamic teachings on environment and the objectives of Islamic Law in protecting the human health and preserving the environment. The manufacturing of LMOs by using biotechnology should comply with one of the objectives of Islamic Law namely to protect the life of the people. ${ }^{155}$ Thus, the PP is in accordance with the verses of the Qur'an which orders human being to maintain the balance as the world was created in definite proportion. ${ }^{156}$

Likewise, the prohibition on causing harm is clearly stated in the Qur'an, ${ }^{157}$ whether obviously or potentially. It is not lawful for a Muslim to cause harm to himself ${ }^{158}$ or to other people. ${ }^{159}$ Thus, the PP is in conformity with the Islamic teachings on environment and protection of human health. Therefore, the application of PP in the manufacturing, exporting and importing of GM crops and GM food is in line with the objective of Islamic Law in protecting life. Based on the

153 Mawil Izzi Dien, Islam and the Environment, Theory and Practice, Theology and Religious Studies \&Muslim studies, <http://www.captivesminds.org/env/ecome>, accessed on 14 February, 2010.

154 Nurdeng Deuraseh, Earth in the Holy Qur'an: How to Protect and to Maintain it? http://www.uhm.my/hadhar/sites/default/files/earth\%20in\%20the $\% 20$ holy $\% 20$ qur'an.pdf, accessed on 30 March. 2010.

155 Sobhi R. Mahmassani, The Philosophy of Jurisprudence in Islam, (Kuala Lumpur: Open Press, 2000), pp. 87-89.

156 See the Qur'an, $25: 2 ; 87: 2 ; 21: 16-17 ; 55: 3-4 ; 55: 8-9$.

157 See the Qur'an, 7:33 in part:

Say: My Lord has forbidden all atrocities, whether overt or disguised, and harm....

See also, the Qur'an, 6:120.

Eschew all sin, open or secret: those who earn sin will get due recompense for their earning.

158 See the Qur'an, 2: 195.

And spend of your substance in the cause of Allah, and make not your own hand contribute to (your) destruction; but do good; for Allah love for those who do good.

${ }^{159}$ See the Qur'an, 6:140.

No mother shall expose her own child to harm, nor shall any father expose his child to harm. 
objectives of Islamic law, protecting the right to live includes protecting the means which facilitate an honourable life such as, freedom to enjoy halal and tayyib food, freedom to enjoy healthy environment, freedom to work, freedom to speech, and freedom to travel. ${ }^{160}$ Hence, protecting human health and environment can be considered as protecting life.

\section{Conclusion}

The relationship between man and environment in Islamic teaching of environment, man is considered as a vicegerent (khalifah) and custodian (trustee). Hence, man has a duty to manage the earth in accordance with the purpose intended by its Creator, to utilise it for his own benefit and the benefit of other beings. Islamic teaching commands Muslims to avoid and prevent mischief, which includes undue exploitation or degradation of environmental resources including the biodiversity. The attitude of Islam to the environment, as the sources of life, is based on prohibition of abuse and promotion of SD.

In the context of state relations with regard to transboundary movement of LMOs, the principle of fairness, justice, equality and mutual respect and consideration for others which are inherent in the moral teachings of Islam are applicable. Thus, in order to protect public health and the environment, states should apply these principles in the export and import of LMOs (GM crops/ $\mathrm{Gm}$ food) in accordance to the Cartagena Protocol. Due to the fact, that there is possibility of adverse impacts of LMOs to human health and the environment, PP has to be applied in the manufacturing and transboundary movement of LMOs.

PP is not expressly identified in the Qur'an and the Sunnah, nevertheless, the notion of PP can be derived from the secondary sources of Islamic law, namely: sadd al-dhara'i, because the doctrine of sadd al-dhara'i is established on the idea of deterrence of evil before it occurs. Thus, sadd aldhara' $i$ ' especially the third and the fourth type of dhara' $i$ is the most appropriate to deduce the legal basis of permissibility of PP in Islamic Law.

Manufacturing and transboundary movement of LMOs cannot be forestalled in international trade. However, these activities are not regulated in the Qur'an and Hadith either. Therefore, the justification for these activities should be found in maslahah mursalah. The principle of maslahah mursalah can be used to justify the manufacturing, and transboundary movement of LMOs. In the sense, that the maslahah mursalah protects both the interest of the exporting and importing states.

Nonetheless, if the manufacturing and transboundary movement of LMOs cannot be classified as maslahah al -daruriyyah, this matter may be prohibited by the states, since, there may be some adverse impacts of the

\footnotetext{
160 Mashhad Al-Allaf, Muslim Divine Law (Shari'ah) the Objectives (Maqasid) of the Muslim Divine or Law Maqasid Theory, http://www.muslimphilosophy.com/ma/works/maqasid.pdf, accessed on 23 May, 2010. See also, Kamali, Principles of Muslim Jurisprudence, op. cit., pp. 274-275.
} 
LMOs in the long run which is not certain, and the PP should be applied. It follows that the interest should be one of the essential (hajiyyah) or the necessity (hajiyyah) and not of the perfectionist or luxury (tahsiniyyah) type, because the intention of maslahah tahsiniyyah is not crucial to protect the life.

Moreover, most Muslim States which are Members of the WTO have an obligation not only to comply with the WTO obligations, but also to exercise the obligations in line with the objectives of Islamic law. States should guarantee that LMOs that they import are lawful (halal) and good (tayyib). Thus, in order to maintain their obligations, states have the authority to protect public health, environment, and biodiversity.

Finally, keeping in view to maslahah mursalah and the trusteeship (amanah) concept, whatever is produced using genetic engineering must be halal and ţayyib, and should not adversely affect human, animal, plant life, or health and their wellbeing. It is also supported by the basic Islamic principle of maintaining balance ( $q a d r$ ) in the environment. If LMOs does not conform to these Islamic principles, Islam would not allow them to be commercialised locally and internationally. 


\section{BIBLIOGRAPHY}

\section{Book}

Ahmad, Wan Azhar Wan. Public Interest (Al-Masalih Al-Mursalah) in Muslim Jurisprudence: An Analysis of the Concept in the Shafi'i School. Kuala Lumpur: the International Institute of Muslim Thought and Civilization, IIUM, 2003.

Ahsan, Khan Nyazee Imran Muslim Jurisprudence Islamabad: the International Institute of Muslim Thought,2000.

Ali, Ahmad.Cosmopolitan Orientation of the Process of International Environmental Law Making. Boston: University Press of America, 2001.

Al-Matroudi, Hakim Abdul I. The Hambali School of Law and Ibn Taymiyyah Conflict or Conciliation.New York: Routledge, 2006.

Alwi, Haji Hassan Abdullah.Sales and Contract in Early Muslim Commercial Law. New Delhi: Kitabbhavan, 2006.

An-Na'im, Abdullahi Ahmad.Toward an Muslim Reformation, Civil, Liberties, Human Rights, and International Law.New York: Syracuse University Press, 1990.

Baharuddin, et. al. eds.Islam and Ecology: A Bestow Trust. Massachusetts: Cambridge, Harvard University Press, 2003.

bin Ghazali, Aidit. Eds. Islam and Justice.Malaysia: Institute of Muslim Understanding, 1993.

Hallaq, Wael B.An Introduction to Muslim Law.United Kingdom: Cambridge University Press, 2009.

Hunud, Abia Kadouf and Al Junid Sharifa Zubaidah.Eds.Land Use Planning and Environmental Sustainability in Malaysia. Kuala Lumpur: IIUM, 2006.

Ibn Ishaq. The Life of Muhammad. Translated by A. Guillaume. London: Oxford University Press, 1955.

Iqbal, Sheikh Mohd. Muslim Toleration and Justice Non-Muslims under Muslim Rule.New Delhi: Adam Publishers and Distributors, 2005. 
Jasser, Auda.Maqasid Al-Shari 'ah As Philosophy of Muslim Law. London: the International Institute of Muslim Thought, 2008.

Kamali, Mohammad Hashim.Muslim Commercial Law an Analysis of Futures and Options.Kuala Lumpur, Malaysia: Ilmiah Publishers, 2002.

Principles of Muslim Jurisprudence. United Kingdom: Cambridge: The Muslim Text Society, 2006.

Publication, 2008.

Shari'ah Law an Introduction. England: Oneworld

Khan, Niazi Liaquat Ali.Muslim law of Contract.Lahore: Research Cell, Dyal Sing Trust Library, 1998.

Khan, Tauqir Muhammad.Jurisprudence in Islam.New Delhi: Pentagon Press, 2007.

Ma'sum, Billah Mohd.Applied Muslim Law of Trade and Finance, A Selection of Contemporary Practical Issue.Selangor: Sweet and Maxwell Asia, 2007.

Mahmassani, Sobhi R. The Philosophy of Jurisprudence in Islam.Kuala Lumpur: Open Press, 2000.

Mawil, Izzi Dien.Muslim Law from Historical Foundations to Contemporary Practice. Edinburgh: Edinburgh University Press,2004.

Michael, Mumisa.Muslim Law Theory and Interpretation. Beltsville, Maryland: Amana Publication, 2002.

Muhammad, Hamidullah.The Muslim Conduct of State.Hyderabad: Deccan, 1977.

O'Brien, John.International Law. United Kingdom: Cavendish Publishing Limited, 2002.

Sayyid, Qutb.Social Justice in Islam.Translated by John B. Hardie, Revised Translation by Hamid Algar. Kuala Lumpur: Muslim Book Trust, 2000.

Secretariat of The Convention on Biological Diversity Biosafety. Handbook of The Convention On Biological Diversity. London: Earthscan Publication, 2001. 
Securities Commission Malaysia.Muslim Commercial Law (Fiqh alMuamalat), Selangor, Lexis Nexis Malaysia.Sdn.Bhd,2009.

Tanzeem, Fatima Muslim Law and Judiciary. New Delhi: Deep \& Deep Publications PvT, Ltd, 2001.

Taymiya, Ibn. Public Duties in Islam the Institution of the Hisba.Translated by Muhtar Holland. Leicester, United Kingdom: the Muslim Foundation, 1982.

Thomison, Andrew. "A New and Controversial Mandate for the SPS Agreement: The WTO Panel's Interim Report in the EC-Biotech Dispute."Columbia Journal of Environmental Law 32 (2007): 287.

Weeramantry, C.G. Muslim Jurisprudence: An International Perspective, Hampshire. London: Macmillan, Houndmills, Basingtoke, 1998.

Muhammad, Akram Laldin. Introduction to Shari'ah and Muslim Jurisprudence. Kuala Lumpur, Malaysia: Cert Publications, 2006.

Ma'sum, Billah Mohd. Applied Muslim Law of Trade and Finance, A Selection of Contemporary Practical Issue. Selangor Malaysia: Sweet and Maxwell Asia, 2007.

Securities Commission Malaysia. Muslim Commercial Law (Fiqh alMuamalat). Selangor, Malaysia: LexisNexis Malaysia Sdn. Bhd., 2009.

Farooq, Hassan. The Concept of State and Law in Islam. Boston: University Press of America.Inc, 1981.

Iqbal Sheikh Mohd, Muslim Toleration and Justice Non-Muslims under Muslim Rule, New Delhi: Adam Publishers and Distributors, 2005.

IshaqIbn, The Life of Muhammad. (A. Guillaume, Trans.). London: Oxford University Press, 1955, at 552-553.

Rahma Hersi, "A Value Oriented Legal Theory for Muslim Countries in the 21st Century: A Comparative Study of Both Muslim Law and Common Law Systems", LL.M. Thesis Indiana University School of Law 2009.

Hashim, Kamali Mohammad. Muslim Commercial Law An Analysis of Futures and Options. Selangor Malaysia: Ilmiah Publishers, 2002. 


\section{Articles}

Aliason, Antonia. "Science versus Law in WTO Jurisprudence: The (Mis)interpretation of the Scientific Process and the (In)sufficiency of Scientific Evidence in EC-Biotech." New York University Journal of International Law \& Politics, Vol. 41 (Winter, 2009): 342-392.

Benda, Stan. "It is all about Elmer Gantry ... There is no Frankenstein! - Part II. " Intellectual Property Journal, Vol. 16, (June, 2003): 393

Coburn, Cora V. "Out of the Petri Dish and Back to the People: a Cultural Approach to GMO Policy." Wisconsin International Law Journal, Vol. 23 (Spring, 2005).

Dresden, Cynthia. "Biotechnology in the Balance of International Trade: Scientific Uncertainty and Legal Response." Currents International Trade Law Journal, Vol. 12, (2003).

Guruswamy, Lakshman D. "Sustainable Agriculture: Do GMOs Imperil Biosafety?.” Indian Journal of Global Legal Studies, Vol. 9, (2002)

Haniff, Ahamat. "The Position of Syiar on Free Trade a Historico-Legal Analysis", Journal of the History of International Law, Vol. 12, (2010), 320-321.

Heavin, Heather D. "The Biosafety Practice and the SPS Agreement: Conflict and Dispute Resolution." Journal of Environmental Law \& Practice, Vol. 12 (November, 2003).

Marc, Victor. "Precautionary or Protectionism? The Precautionary Principle, Genetically Modified Organisms, and Allowing Unfounded Fear to UndermineFree Trade.” Transnational Law Journal, Vol. 14, (2001).

Marong, Alhaji B. M. "From Rio to Johannesburg: Reflections on the Role of International Legal Norms in Sustainable Development." Georgia International Environmental Law Review (Fall, 2003).

Percival, Robert V. "Who is Afraid of the Precautionary Principle?." Pace Environmental Law Review (2005-2006).

Redick, Thomas P. "The Cartagena Protocol on Bioafety: Precautionary Priority in Biotech Crop Approvals and Containment of Commodities Shipments." Colombia Journal of International Environmental Law \& Policy (2007). 
Saigo, Holly. "Agricultural Biotechnology and the Negotiator of the Biosafety Protocol.” Goergia International Environmental Law Review. Vol. 12. (Spring, 2000).

Thomison, Andrew.Andrew, "A New and Controversial Mandate for the SPS Agreement: The WTO Panel's Interim Report in the EC-Biotech Dispute", Columbia Journal of Environmental Law, Vol. 32 (2007):287.

\section{Internet}

Abdalhamid, Evans. "Are Muslim Eating Halal in Canada?". <http://www.shiachat.com/forum/index.php?/topic/234920695-eatinghalal-in- canada?> . Accessed on 24 January, 2011.

Abdul, Hanan Shah "Usul Al Fiqh (Muslim Jurisprudence)", $<$ http://www.bandung2.co.uk/books/files/hw/usul \%20Al-Fiqh\%20\%20 Abdul\%20Hamman.pdf>. Accessed on 3 February, 2011.

Abdullah, Yusuf Ali. "Qur'an Viewer 2.8" the English Transliteration by Commentary Chapter Introductions by Scholar, Shed Abu AlMaududi, Transliteration Text by Muslim Net, adapted by Jamal Al-Nasir

Abul, Hassan. "On Islam's Attitude towards Sustainable Development". <http://www.muslimcenter.kaau.edu.sa/arabic/maqallah/pdf $>$. Viewed on 27 January, 2010.

Adam, Ben "The Creation of Environmental Conscience (part 2 of 4): ManGod's Steward on the Earth". <http://www.islamreligion.com/articles/334.html $>$. Accessed on 25 January, 2010.

AFIC School, Halal Services, Halal Acreditation, Muslim Australia "HalalGeneral Definition". <http://www.afic.com.au/3=Q65> Accessed on 30 March, 2010

AFIC Schools, “Halal General Definition”. $<$ http://www.afic.com.au/?p=405> Accessed on 21 December, 2010.

Ahmed, Khan Niaz. "Sustainable Development and Muslim Ethics: A Primer 
context/uploads/2010/03/Sustainable_development_and_Muslim_Ethic s_by_Dr-Niaz-Ahmed-Khan.pdf>. Accessed on 4 June, 2010.

Ali, Ahmad. "Cosmopolitan Orientation of the Process of International Environmental Law Making, (Boston, University Press of America.Inc, 2001)

Al-Khouli, Saiyed F. "On Islam Attitude Towards Sustainable Development” $<$ http://www.isesco .org.ma/english/publications/Sust_Der/P6.php>. Accessed on 20 January, 2010.

Amery, Hussein A. "Islam in the Environment" <http://www.idre.ca/en/eu.9350-201-I-Do-Topic.html>. Accessed on 23 February, 2009.

Ansari, Mohammed I. "Muslim Perspective on Sustainable Development". $<$ http://i-

epistimology.net/attacthments/406_V1IN3\%6Fall\%2094\%20Ansari\%2 $\underline{0-}$

\%20Muslim\%Perspectives\%20on\%20Sustainable\%20Development.pdf $>$. Accessed on 12 January, 2010.

Asma, Hassan and Cajee Zainal Abedien. "Muslims and Sustainable Development: the Message from Johannesburg" <http: //www.imase.org/content/view/27/34/>. Accessed on 31 December, 2009.

Association of American Halal Certifier. "Halal Defined". $<$ <http://aahalalcert.org/halalDefined.htm > .Accessed on 2 January, 2011.

Aurangzeb, Ahmad M. "Is A Greener Islam Possible?". <http://www.altmuslim.com/a/a/a/is_a_greener_islam_possible?Aurang zeb> Accessed on 24 May, 2010.

Azim, Islahi Abdul. "Economic Thought of Ibn Al Qayyim”, King Abdulaziz University, International Centre in Muslim Economic. <http://www.hantakji.com/fiqh/Files Economics/c433.pdf>. Accessed on 4 February, 2011.

Bawa, Muhaiyaddeen. "Environmental Protection in Islam (part 1 of 7): General Introduction”, Muslim Realisation Society. <http://www.islamset.com/env/index.html>. Accessed on 20 October, 2009. 
Beekun, Rafik I. and Badawi Jamal A., "Balancing Ethical Responsibility Among Multiple Organisational Stakeholder: The Muslim Perspective". <http: www.business.unr.edu/faalty/beekun/beekun\%20and\%20Badawi\%20J BE\%20pub.pdf>. Accessed on 23 November, 2009.

Billah Mohd Ma'sum, Applied Muslim Law of Trade and Finance, Malaysia, Sweet and Maxwell Asia, 2007.

Buang Ahmad Hidayat and Zahara Zalina, "Tapping into the World Halal Market: Some Discussions on Malaysian Laws and Standards". Shariah Journal. Vol. 66. Special. Edition (2008), 603-616. <http://myais.fshtm.um.edu.my/9595/I/TAPPING_INTO_THE_WORL D_HALAL_MARKET_SOME_DISCUSSIONS_ON_MALAYSIAN_ LAWS_AND_STANDARDS.pdf> Viewed 0n 29 December, 2010.

Chapra, M Umar Muslim Civilisation the Causes of Decline and the Need for Reform, United Kingdom: the Muslim Foundation, 2008, at 20-21.

Choudhury Masudal Alam "The Humanomic Structure of Muslim Economic Theory: A Critical Review of Literature in Normative and Positive Economics".

<http://www.kantaleji.com/figh/Files/Economics/10058.pdf $>$ Accessed on 14 February, 2010.

Cisse Tony, "Islam, the Environment and the Use of Vetiver Grass". <http://www.fetiver.org/SEN-Cisse2.pdf> Accessed on 5 January, 2010.

Dāwud, SunanAbūBook III, 1020, Hadith no. 3587. Islamsoft-Solution, the Future Toward Universe of Revolutionised Software <http://www.islamsoft.co.uk>Viewed on 12 February, 2010.

Deuraseh Nurdeng, "Earth in the Holy Qur'an: How to Protect and to Maintain it <http://www.uhm.my/hadhar/sites/default/files/earth\%20in\%20the\%20 holy\%20qur'an.pdf> Accessed on 30 March. 2010.

Discover Islam Web. "Economics Principles of Islam". <http://www.witness.pioner.org/vil/Books/Mf_ICIT/Islam_principle.ht $\underline{\mathrm{ml}}>$. Accessed on 8 February, 2010.

Eddine, Kharoufa Ala. "Philosophy of MuslimShari 'ah and Its Contribution to the Science of Contemporary Law". <http://Muslimstudies.islammessage.com/panel/media/philosophy-ofMuslim-Shariah.pdf>. Accessed on 3 February, 2011. 
Fadl, Khaled Abou El, "Islam and the Challenge of Democracy". $<$ http://www.princeton.edu/iisd/project/PORDIR/research/khalid \%20 Abau\%20 E 520 Fadl.pdf > . Accessed on 20 December, 2010.

Fahim H.A., "GMO Product from the Muslim Perspective: Are They Halal (Lawful) or Haram (Unlawful)?”.IFT Annual Meeting, July 15-20, 2005, New Orleans, Louisiana.

Faroog, Hassan. "Islam: Environmental Protection". <http://www.greaterdemocracy.org/archieves/000507.html >. Accessed on 10 January, 2009.

Fazlun M., Khalid. "Islam and Environment" in Encyclopedia of Global Environmental Change. Ed. Peter Timmerman, (Chichester John Wiley \& Sons, Ltd, 2002.

Gopo, Josept M. "Biosafety and Trade: Issues for Developing Countries", Bellevau, Switzerland 18-10 July 2001, <www.ictsd.org>. Accessed on 24 July 2008.

Habibah Hayati, et. al., "Quality Assurance in Halal Food Manufacturing in Malaysia: A Preliminary Study", Proceedings of International Conference on Mechanical \& Manufacturing Engineering (ICME2008), 21-23 May 2008, Johor Bahru, Malaysia. Faculty of Mechanical \& Manufacturing Engineering, University Tun Hussein Onn Malaysia (UTHM), Malaysia.

Hadith Sahih Muslim, Hadith 10, No: 1015. Nawawi.s Collection of 40 $\times$ Hadith on Video. http://muslimtube.net/search_result.php? search_id=Nawawi=Hadith\&dtk_searchsubmit.x=0\&dtk_searchsubmit. $\mathrm{y}=0 \&$ search_ty $=$ =serach_videos. Accessed on 25 November, 2010.

Hadith Sahih, Buchari book 39, No. 513, Islamsoft-Solution, the Future Toward Universe of Revolutionised Software <http://www.islamsoft.co.uk> Accessed on 12 February, 2010.

Hadith.Sahih Muslim. No. 4358.Islamsoft-Solution, the Future Toward Universe of Revolutionised Software 〈http://www.islamsoft.co.uk $>$ Accessed on 27 January, 2010.

Haji Hassan Abdullah Alwi, Sales and Contract in Early Muslim Commercial Law, New Delhi, India, Kitabbhavan, 2006.

Halal Certification "What is Haram?" $\langle$ http://swisshalal.ch/archives/72 $>$. Accessed on 22 December, 2010. 
Halal Food Council SEA. "Certification Requirements". 〈http://halalfoodcouncil.info/certification requirement.html >. Accessed on 26 December, 2009.

Halal Market Consultant, "Halal Market Analysis", Halal Market Intelligence Newsletter, <http://halalfocus.com/artman2/uploads/1/Halal_market_intelligence_n ews_may_07. pdf >. Accessed on 22 December, 2010.

Hashim, Kamali Mohammad. "Environmental in Islam: A Qur'anic Perspective". The Royal Aal al-Bayt Institute for Muslim Thought, the 15 $5^{\text {th }}$ General Conference, 27-29 September, 2010. $\langle$ http://www.aablbyt.org/Env Conference/002.pdf $>$. Accessed on 23 December, 2010.

Imam, Muslim MukhtasarSahih Muslim. (Abdul Hamid Siddiqi, trans.), New Delhi: Kitab Bhavan, 2000, vol. 6, at 2.

Islam from Inside. "Man and Ecology: An Muslim Perspective". <http://www.Islaminside.com/Pages/Articles/Ecology\%20Environment \%20and \%20Islam.html>. Accessed on 16 February, 2010.

Islam Green Team. "Islam and the Environment". <http://muslimgreen team.org/Islam-and-the-environment >. Accessed on 12 January, 2010.

Islam Religion Com. "Justice in Islam". $\langle$ http://www.islamreligion.com/articles/376 $>$. Accessed on 4 July, 2010.

Islam Set, Science Environment and Technology. "General Introduction to Islam's Attitude toward the Universe, Natural Resources and the Relation between Man and Nature". $<$ http://www.islamset.com/env/index.html $>$. Accessed on 20 January, 2010.

Islam Set, Science Environment and Technology. "Legislative Principles, Policies and Institutions of Muslim Law which Govern the Procedure and Measures for the Protection and Conservation of the Environment". <http://www.islamset.com/env/index/html $>$. Accessed on 20 January, 2010.

Islam Set, Science, Environment and Technology, "Seminar on Genetics, Genetic Engineering, the Human Genes, and Genetic TreatmentAnMuslim Perspective", 1998. <http://www.Islamset.com/biothics/genetics/genetics.html $>$. Accessed on 10 February, 2010. 
Iyat, Abumoghli. "Sustainable Development in Islam". <http://waterwiki.net/images/8/85/sustainable

_development_in_Muslim_law_Iyad_A bumoghli.doc > . Accessed on 25 January, 2010.

Izzi, Dien Mawil. "Islam and the Environment, Theory and Practice". Theology and Religious Studies \&Muslim studies. <http://www.captives minds.org/env/ecome >. Accessed on 14 February, 2010.

Jabatan Kemajuan Islam Malaysia (JAKIM), 〈http://Halaljakim.gov.my/corporate.html> Accessed on 12 January, 2010.

Kamal, F. "Islam and the Environment". <http://www.easily-understandislam.com/articles/Islam-environment.html>. Accessed on 15 January, 2010.

Kari, Ansari. "IFANCA: Leader in Promoting Halal to America's Consumers".

$<$ http://americanhalalassociation.org/AHA/HalalConnect_files/HalalCo nnect\%20 Binder\%20.pdf >. Accessed on 26 February, 2010.

Karim, Hamdy. "Muslim Perspectives on Natural Resources Management and Sustainability".

$\langle$ http://oregostate.edu/dept/iifet/2000/papers/hamdy.pdf $>$. Accessed on 23 February, 2010.

Latifah, Amin, et. al., "Muslim Ethics and Modern Biotechnology". <http://www.Sarionline.ukm/SARI\%2027(2)/SARI27\%5B2\%5D2009 \%20\%5B13\%5D.pdf> Accessed on 26 February, 2010.

London Borough of Hackney, London Central Mosque \& the Muslim Culture Centre. "A Food Guide for Muslim Trader". <http://www.iccereives.org.uk/downloads/halal-leaflet/halal-trader-seng.pdf $>$. Accessed on 24 December, 2010.

Lucita, Ball. "Green Deen vs Gloom and Doom". $<$ http://www.shapworkingparty.org.uk/journals/articles_08109/ball_lon g.pdf $>$. Accessed on 10 January, 2010.

Mamoun, Abuarqub. "Muslim Imperatives to Curb Corruption and Promote Sustainable Development". $\quad$ http://www.Muslimrelief/com/Indepth/Downloads/Muslim\%20imperatives\%20to\%20curb \%20corruption\%20promote\%20sustainable\%20development.pdf >.

Accessed on 21 June, 2010. 
Mashhad, Al-Allaf . "Muslim Divine Law (Shari'ah) the Objectives (Maqasid) of the Muslim Divine Law or Maqasid Theory". <http://www.muslimphilosophy.com/ma/works/maqasid.pdf $>$.

Accessed on 23 May, 2010.

Mehmet, Usutay. "A Political Economic Approach to Muslim Economics: Systemic Understanding for an Alternative Economic System”. Kyoto Bulletin of Muslim Area Studies (2007).

Mohammed, Obaidullah. "Ethics and Efficiency in Muslim Stock Market". $<\underline{\text { http:// }}$ phkumweb.ukm.my?_hairon/kertas\%20kerja\%20assignment/Muslim\%

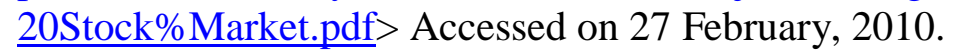

Moral Stories. "Which is Superior: Justice or Generosity ?Concept of Justice in Islam". $\lfloor$ http://www.ezsoftech.com/Stories/justice.in.islam.atp-Moral Stories $>$. Accessed on 20 April, 2010.

Muslim Glossary. "Muslim Glossary and Expression". <http://www.calltoplayer.info/id4.html >. Accessed on 20 October, 2010.

Muslim Relief Worldwide. "Environmental Policy". <http://www.muslimrelief.com/Indepth/downloads/Environmental\%20Policy.pdf $>$.

Accessed on 2 March, 2010.

Muslim Society of North America. "Halal Product". <www.nussack.com/finemeat/halal.php>. Accessed on 23 December, 2010.

Muzammal, Hussain. "Islam and Climate Change: Perspectives and Engagement”, (March 2007) <http://www.lineonweb.org.uk/Resources/reading.htm>. Accessed on 20 December, 2009.

Nazeem, Goolam Hafiz. "Preserving Paradise Through Religious Values of Nature: Muslim Approach". <http://www.fs.fed.us/rm/pubs/rmrs_p027/rmrs_p027_105_166.pdf $>$. Viewed on 24 January, 2009.

Nurliza, Ramli.. "xalÉl- The New Global Trade Force". <http://www.lexmundi.com/images/lexmundi/PDF/Skrine-NR.pdf > Accessed on 29 December, 2010. 
Rached, Al-Jayyousi "Grey Water: Muslim Perspective”. <http://www.idrc.ca/cp/ev-152692-20/-I-Do_ToP/c.html>. Accessed on 24 February, 2010.

Safian, Moch. and Hanani Yasmin. "Islam and Biotechnology: With Special Reference to Genetically Modified Food". $\langle$ http://www/metanexus.net/conference 2005/pdf/mohd_safian.pdf $>$. at 10. Accessed on 15 January, 2009.

Saifuddeen, Shaikh Mohd. "Religious Sector Keeping Faith in the Technology".

$<$ http://www.isaaa.org/resources/publications/briefs/40/download/isaaabrief-40-2009-religious-sector.pdf> Accessed on 22 May 2010.

Saliem, Fakir "The Notion of Public goods, Sustainable Development and Islam".

$<$ http://www.islam.co.za/awqafsa/public\%20Goods\%20in\%20Islam\%2 0Fakir.htm $>$. Accessed on 8 February, 2010.

Shanmugan, G. "The BtBrinjal Debate”. <http://www.las.ac.in/currsei/25 jan 2011/147. pdf $>$. Accessed on 22 February, 2011.

Third World Network Biosafety Information Service, "Biosafety Protocol Steps Forward", <http://www.biosafety.info.net/file_dir/516179244cbe5ce34ca39.pdf $>$. Accessed on 28 February 2010.

Wajdi, Dusuki Asyraf and Abdullah Nurdianawati Irwani, "Maqasid alShari'ah and Corporate Social Responsibility" <http:www.kantakjie.com.figh/Files/Accountancy/0308914.pdf>.

Accessed on 23 December, 2009.

Yasin, Dutton "The Source of Muslim Law". <http://www.muhajabah.com/clocstorage/dutton.htm>. Accessed on 4 February, 2011.

Yusuf, Saleem Muhammad. "Methods and Methodologies in Fiqh and Muslim Economics". <http: Muslimcenter.kau.edu.sa/English/English20Papers\%5B21\%sD\%20M. Yusuf\%20saleem.pdf $>$. Accessed on 16 February, 2010.

Zaki, Jalil "Nature of Progress". $<$ http://www.thereadinggroup.sg/Articles/Nature\%20of\%20Progress.pdf >. Accessed on 25 February, 2010. 
Zubair, Hasan. "Sustainable Development from Muslim Perspective: Meaning Implications, and Policy Concern". <http://ideas.refec.org/pa/mpra pa/2784.html > Accessed on 24 February, 2010.

Zulkifly, Hasan. "Muslim Perspective on the Competition Law and Policy". $<$ http://www.wbicompro.com/london\%20management/Hasan (402).pdf $>$. Accessed on 26 February, 2010 